\title{
Ore Geology, Fluid Inclusion Microthermometry and H-O-S Isotopes of the Liyuan Gold Deposit, Central Taihang Mountains, North China Craton
}

\author{
Xiaoqiang Zhu ${ }^{1}$, Jingbin Wang ${ }^{1,2, *}$, Zhenshan Pang ${ }^{1,3, *}$, Shimin Zhen ${ }^{3}$, Fan Yang ${ }^{1,4} \mathbb{D}^{\text {, }}$ \\ Jianling Xue ${ }^{3}$, Hongxiang Jia ${ }^{1}$ and Guangyao Shi ${ }^{5}$ \\ 1 School of Earth Sciences and Resources, China University of Geosciences Beijing, 29 Xueyuan Road, \\ Beijing 100083, China; xqzhu@cugb.edu.cn (X.Z.); yang_fan1989@126.com (F.Y.); \\ cugbjiahongxiang@126.com (H.J.) \\ 2 Beijing Institute of Geology for Mineral Resources, Beijing 100012, China \\ 3 Development and Research Center, China Geological Survey, Beijing 100037, China; \\ zhenshimin001@163.com (S.Z.); xuejianling369@126.com (J.X.) \\ 4 Key Laboratory of Mineral Resources in Western China (Gansu Province), School of Earth Sciences, \\ Lanzhou University, Lanzhou 730000, China \\ 5 Geological Exploration Department, Regional Geological Survey Institute of Hebei Province, \\ Langfang 065000, China; guanguaoshi1990@163.com \\ * Correspondence: wjb@bigm.com.cn (J.W.); pzs927@163.com (Z.P.); Tel.: +86-010-8493-1994 (J.W.)
}

Received: 2 August 2019; Accepted: 26 September 2019; Published: 1 October 2019

\begin{abstract}
The Liyuan gold deposit, located in the central Taihang Mountains, North China Craton, forms an important part of the Taihang polymetallogenic belt. The origin of ore-forming fluids and the genesis of this deposit remains controversial. In this paper, fluid inclusions (FIs) microthermometry and H-O-S isotopes analysis are conducted to constrain the origin of ore-forming fluids and genesis. The main findings are as follows: (1) Three hydrothermal metallogenic stages are identified: Quartz-pyrite, quartz-polymetallic sulfide, and quartz-carbonate stages; (2) three types of primary FIs are recognized: $\mathrm{CO}_{2}$-aqueous (type I), pure $\mathrm{CO}_{2}$ (type II), and aqueous FIs (type III); (3) ore-forming fluids are characterized by medium-low temperatures, medium-low salinity, and $\mathrm{H}_{2} \mathrm{O}-\mathrm{CO}_{2}-\mathrm{NaCl} \pm$ $\mathrm{CH}_{4}$ system; (4) $\mathrm{H}-\mathrm{O}$ isotopes indicate that the ore-forming fluids mainly have a magmatic origin and late-stage ore fluids mixed with meteoric water; (5) $S$ isotopes further confirm that the sulfides most likely have a deep magma source with variation caused by changes in oxygen fugacity; and (6) fluid immiscibility and water-rock interactions are considered to be the two main mechanisms of gold deposition. Due to the lack of large granite bodies exposed in this ore district, we infer that the fluids of gold deposit and quartz porphyry may have both been exsolved from a concealed granite pluton at deeper locations, and we further propose that Liyuan gold deposit is typical magmatic-hydrothermal gold deposits.
\end{abstract}

Keywords: fluid inclusions; H-O-S isotopes; Liyuan gold deposit; central Taihang Mountains; North China Craton

\section{Introduction}

The North China Craton (NCC) hosts hundreds of lode gold deposits and contributes more than two-thirds of the gold production in China (Figure 1) [1-4]. Different types of gold deposits with high economic value (such as massive gold-quartz-pyrite vein type and altered rock dissemination along fracture zone type in the Jiaodong Peninsula) occur in the NCC [5]. While several models have been proposed for the lode gold deposits of the craton, such as orogenic type, Jiaodong type, 
and decratonic type, its genetic classification remains controversial $[5,6]$. The temporal and spatial relationship between the gold deposits and the associated magmatic intrusions suggest that gold metallogeny is linked to the many mafic dykes and granitoid plutons [5]. Previous studies on gold deposits in the NCC have mainly focused on its margins, such as the Jiao-Liao gold province (Eastern margin), Xiong'ershan-Xiaoqinling gold province (Southern margin), and Yan-Liao gold district (Northern margin) (Figure 1b) [7-9]. However, few studies have concentrated on the interior of the NCC, especially in the central Taihang Mountains (TM), where mining of the gold deposits is commonly smaller in scale than those on the margins of the NCC. The central TM preserves important records associated with magmatism and metallogenesis [7]. The deposits discovered in this region mainly include $\mathrm{Au}, \mathrm{Ag}, \mathrm{Cu}$, and Mo deposits, and the gold deposit has great potential for mineral exploration [5]. Therefore, it is necessary to conduct studies in the central TM, which will be helpful to comprehensively understand the gold metallogeny of the NCC and provide associated implications for future mineral exploration in this region.

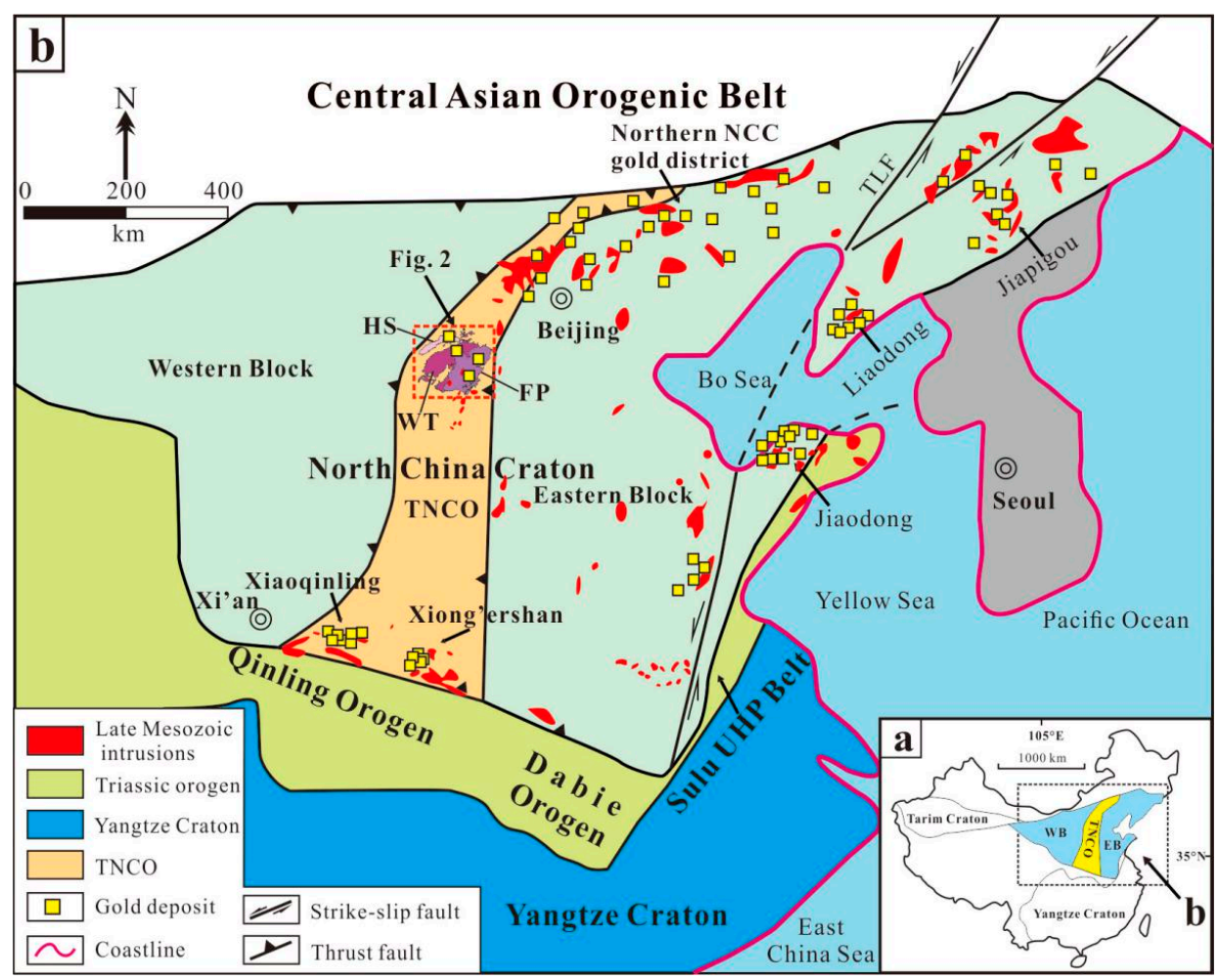

Figure 1. (a) Tectonic map showing the location of the North China Craton (modified after Reference [10]); (b) geological map of the North China Craton showing the tectonic divisions, distribution of metamorphic core complexes, late Mesozoic intrusions, and major, large gold districts (modified from References [11-19]). Abbreviations: EB, Eastern Block; WB, Western Block; TLF, Tan-Lu Fault; TNCO, Trans-North China Orogen; FP, Fuping Complex; WT, Wutai Complex; and HS, Hengshan Complex.

The Liyuan gold deposit, a newly discovered deposit in the interior of the NCC, is also located in the central TM (Figure 1). Previous studies mainly focused on the geology of this deposit, the origin and evolution of its ore-forming fluids, the source of ore-forming material, the metallogenic epoch, and the ore genesis [20-23]. However, the source and evolution of ore-forming fluids, together with the materials and genesis of this deposit, remain controversial. Xu [20] and Ju et al. [21], respectively, classified this gold deposit as an alteration rock type controlled by fractures and a magmatic-hydrothermal alteration rock type, but both accepted that the ore forming fluids were of magmatic origin. However, Ma et al. [22,23] argued that this deposit is an orogenic type and the ore forming fluids were likely magmatic water or of metamorphic origin. Accordingly, detailed 
studies related to the source of ore-forming fluids and materials are worthy of constraining the gold deposition mechanism and ore genesis, which also largely restricts future prospecting work in the Liyuan gold deposit.

In this study, based on field and petrographic observations, we present new fluid inclusion (FI) and stable isotope data from the Liyuan gold deposit, aiming to: (1) Reveal the origin and evolution of the ore-forming fluids and materials; (2) probe into the mechanism of gold deposition; (3) constrain the ore genesis; and (4) provide some implications for future exploration of gold deposits in the NCC interior. By combining the data from regional and deposit geology, a possible genetic model for the Liyuan gold deposit is proposed in this study.

\section{Geological Setting}

The NCC, as one of the oldest Archean cratons in the world, is bounded by the Central Asian Orogenic Belt (CAOB) to the North and Qinling-Dabie-Sulu high to the ultra-high-pressure metamorphic belt to the South (Figure 1) [24-28]. The NCC has been divided into the Western Block (WB) and Eastern Block (EB) along the central zone that formed during the collision between the two blocks at ca. $1.85 \mathrm{Ga}$, also known as the Trans-North China Orogen (TNCO) (Figure 1b) [28]. The Taihang Mountains region is located in the central part of the NCC [29]. The study area for this paper is distributed in the Northern part of the central Taihang Mountains (Figure 1b) [30].

The early Precambrian basement rocks of the central TM mainly consist of the Hengshan, Wutai, and Fuping Complexes from North to South (Figure 2). These complexes were predominantly composed of gneiss, schist, marble, amphibolite, and banded iron formation in association with trondhjemite-tonalite-granodiorite gneiss (TTG) [27,29,31,32].

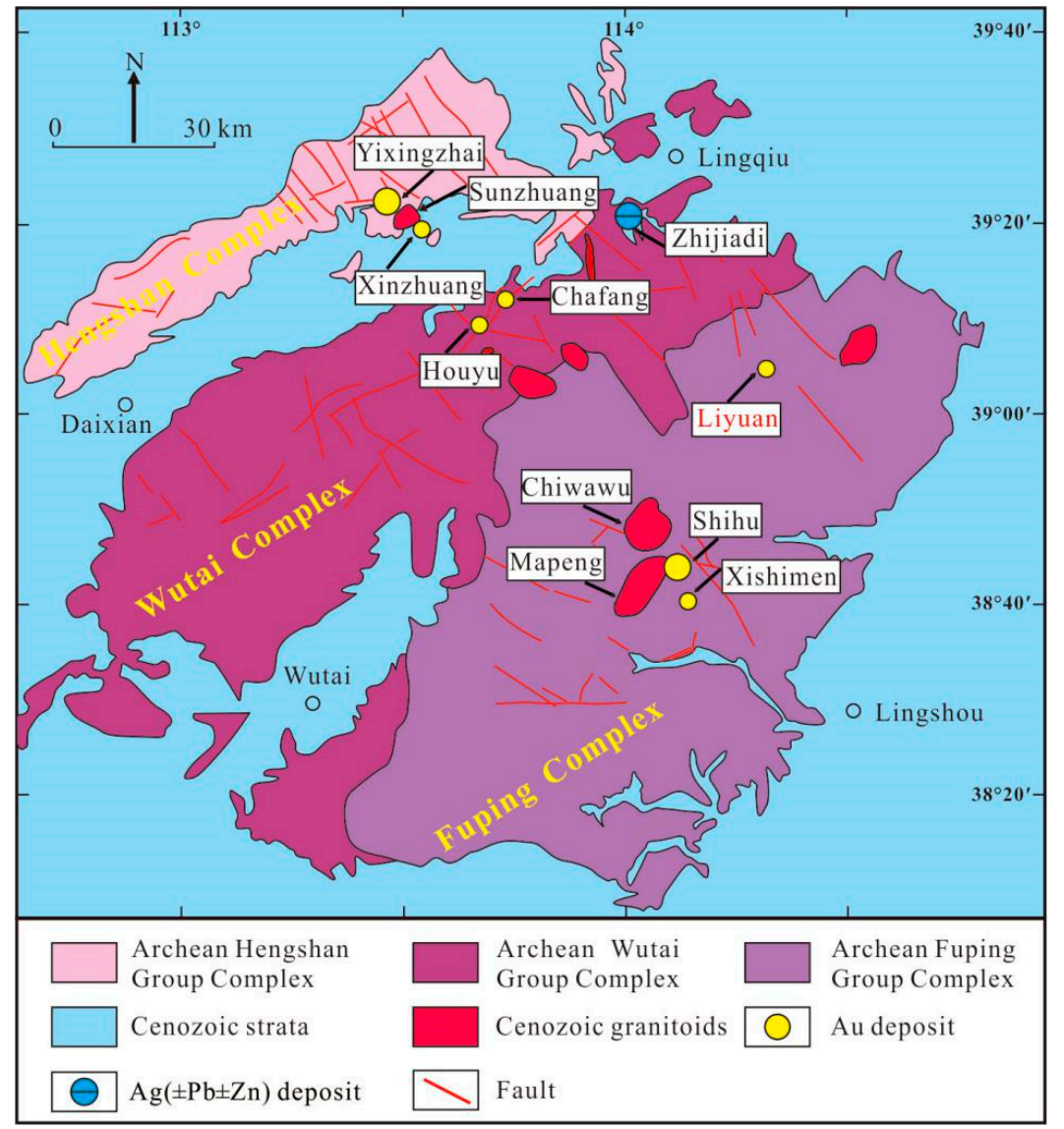

Figure 2. Sketch map of the distribution of gold deposits in the central Taihang Mountains (modified after References $[7,33,34])$. 
In the central TM, the early structures show NNW- and E-W-trending faults, which were formed during the Mesoarchean to Paleoproterozoic periods, with the NNW-trending faults carrying late Paleoproterozoic mafic dikes [7]. A series of N-S-, NW-, E-W-, and NE-trending faults were generated from late Mesozoic (Yanshanian) tectonic movements. Several Cretaceous (e.g., Mapeng) granitoid plutons were emplaced at the junctions of fault systems (Figure 2). The intermediate-felsic dikes commonly intruded into the NE- and N-S-trending faults [7].

Many Yanshanian intrusions were exposed in the TM (Figure 2), such as the Dahenan, Chiwawu, Mapeng, Wang'anzhen, and Sunzhuang plutons, with an emplacement age of ca. 130 Ma [32,35]. The metallic minerals contained $\mathrm{Au}, \mathrm{Ag}, \mathrm{Cu}$, and $\mathrm{Mo}$, and polymetallic ore deposits were mainly distributed in the central TM. Large-scale ore deposits included the Shihu and Yixingzhai gold deposits, which have been intensively investigated in recent years [32,36-40]. The mineralization fluids and ore minerals in the Shihu and Yixingzhai gold deposits were derived from magma generated in the lower crust with partial mantle input [32,36], and the timing of metallogeny associated with magmatism in the region was ca. $130 \mathrm{Ma}[32,39,40]$.

\section{Ore Geology}

\subsection{Stratigraphy}

The Liyuan deposit is located approximately $72 \mathrm{~km}$ South of Lingqiu County, Shanxi Province (Figure 2). The basement rocks exposed in this deposit belong to the late Archean Fuping Group, which is dominated by migmatitic K-feldspar granite and high-grade metamorphic gneiss intercalated with plagioclase amphibolite (Figure 3a).

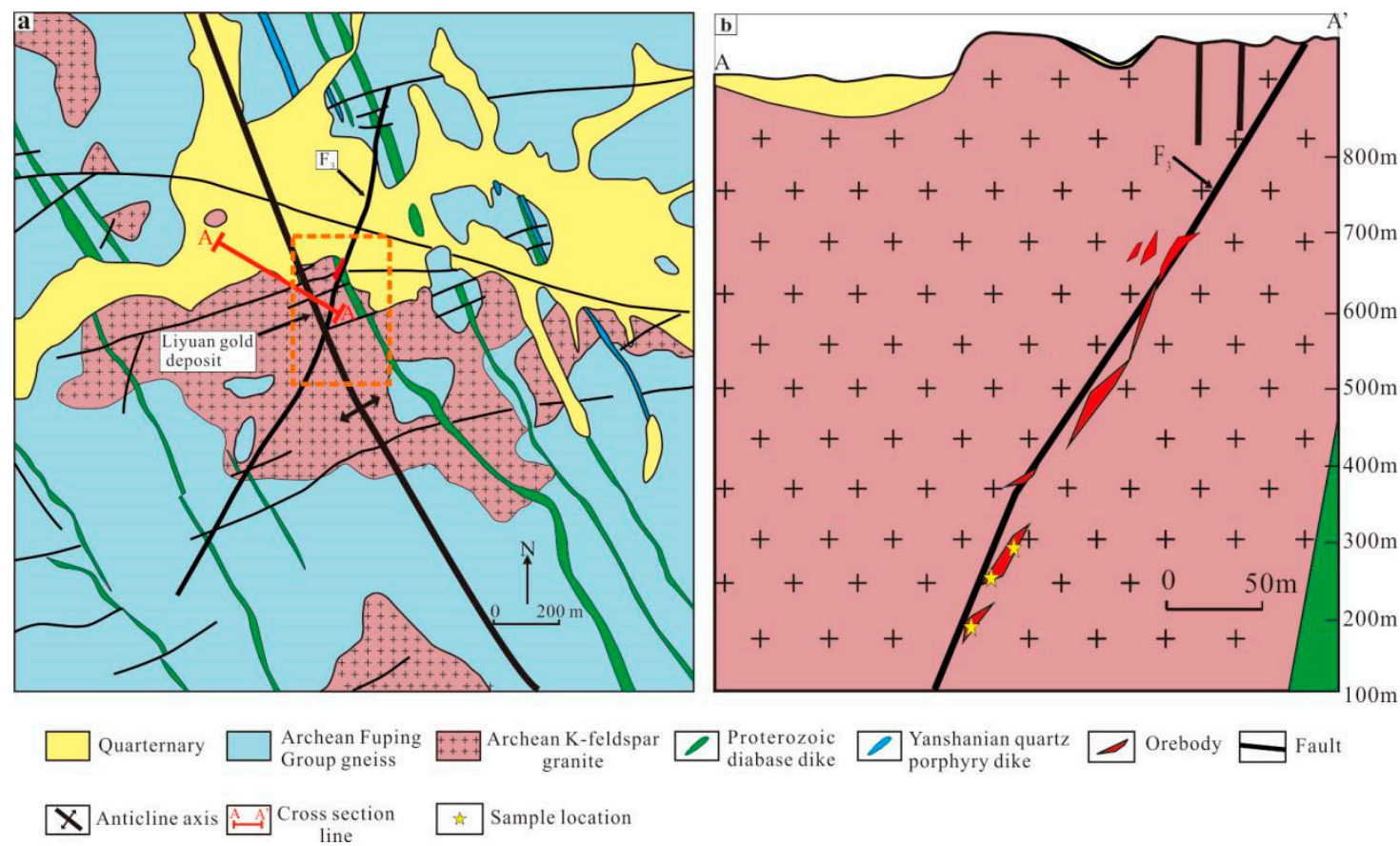

Figure 3. (a) Geological map of the Liyuan gold deposit (modified after Reference [41]); (b) cross section of the Liyuan gold deposit showing the geometry of orebodies (modified after Reference [41]).

\subsection{Structures}

The Liyuan gold deposit is predominantly controlled by a NW-trending anticline and four secondary faults systems (NNE-, NW-, NE-, and near E-W-trending faults) (Figure 3a). $\mathrm{F}_{3}$ (NNE-trending) is the major ore-controlling fault, with a length of $2000 \mathrm{~m}$ and a width of 1-15 m (Figure 3a), trending from 10-30 and dipping at angles of $45-65^{\circ} \mathrm{NW}$ [21-23]. These faults were characterized by well-developed fault 
gouge and hydrothermal breccias, which may indicate multistage deformation events. Furthermore, the NW-trending faults were the earliest faults in the mining area, characterized by the intrusion of diabase dikes. The near E-W-trending faults formed after the mineralization and cut across the orebodies.

\subsection{Igneous Rocks}

Only diabase dikes and quartz porphyry dikes were exposed in the Liyuan ore district (Figure 3a). There were tens of NW-tending diabase dikes, with lengths of $2000 \mathrm{~m}$ and widths of 20-30 m (Figure 4b). These dikes occurred throughout the whole mining area, and several dikes were cut by orebodies with strong deformation and alteration, implying an earlier age than mineralization (Figure 3a). The junctions between diabase dikes and faults provided favorable space for the precipitation of ore-forming fluids. These exposed diabase dikes yielded laser ablation inductively coupled plasma mass spectrometry (LA-ICP-MS) zircon U-Pb age of $1788 \pm 13 \mathrm{Ma}$ [23]. Three quartz porphyry dikes, exposed in the Southern and Eastern parts of the ore district (Figures 3a and $4 \mathrm{a}$ ), were characterized by K-feldspathization, sericitization, and pyritization. Zircon U-Pb dating results showed the timing of emplacement of quartz porphyry at $134.1 \pm 1.1$ Ma during the Early Cretaceous, in accordance with the sericite ${ }^{40} \mathrm{Ar} /{ }^{39} \mathrm{Ar}$ plateau age of $133.3 \pm 1.2 \mathrm{Ma}$ [22], which indicated a temporal relationship between the quartz porphyry and the gold deposit. While no other granitic rocks were found in the study area (Figure 3a), geophysical data suggested that a concealed intermediate-acid granitic pluton might have underlain the Liyuan orebodies [42].

\subsection{Orebodies and Ores}

The gold orebodies of the Liyuan deposit were mainly hosted in the Archean Fuping Group gneiss and migmatitic K-feldspar granite, and were predominantly controlled by the $\mathrm{F}_{3}$ fault (Figure $3 b$ ). Among the three orebodies developed in the deposit, the largest (No. 1) was the main orebody, which generally appeared as a vein. It has been partially traced for approximately $600 \mathrm{~m}$ in length and extends for more than $200 \mathrm{~m}$, with a thickness of $2-5 \mathrm{~m}$ (average $3.45 \mathrm{~m}$ ). The No. 1 orebody strikes $10-30^{\circ} \mathrm{NE}$ and dips $45-65^{\circ}$ Northwestward from the surface down to $344 \mathrm{~m}$ above sea level. A nearly E-W-trending branch appeared in the middle part of the No. 1 orebody. This orebody had an average gold grade of $3.62 \mathrm{~g} / \mathrm{t}$ with a maximum grade of $300 \mathrm{~g} / \mathrm{t}$ [20].

Major mineralization types at Liyuan included pyrite-sericite-quartz altered rocks (Figure 4f), quartz-pyrite veins (Figure 4e,j), quartz-polymetallic sulfide veins (Figure 4g-k), and brecciated type (see Section 3.5 for the division of mineralization stages).

The main ore textures were euhedral-subhedral, granular, cataclastic, and metasomatic (Figures 4-6). The ores mostly displayed massive, brecciated, mesh-vein, and disseminated structures (Figure 4).

Ore minerals predominantly consisted of pyrite, galena, and sphalerite, with minor chalcopyrite, hematite, and magnetite (Figures 4 and 5a-f). Among them, pyrite (more than $80 \%$ of the ore minerals) was the predominant gold-bearing mineral and showed euhedral or subhedral crystals (Figures 5a-e and 6). Chalcopyrite commonly occurred within pyrite and sphalerite as exsolution inclusions (Figure 5d-f). Gangue minerals are mostly quartz (more than $80 \%$ of the gangue minerals), sericite, and K-feldspar with minor chlorite, muscovite, ankerite, and calcite (Figures 4 and 5). Gold mainly occurred in fissures of pyrite and quartz (Figure $5 c, e$ ) or as inclusions in pyrite and sphalerite crystals (Figure 5d,f), which suggested an existing and close relationship. 


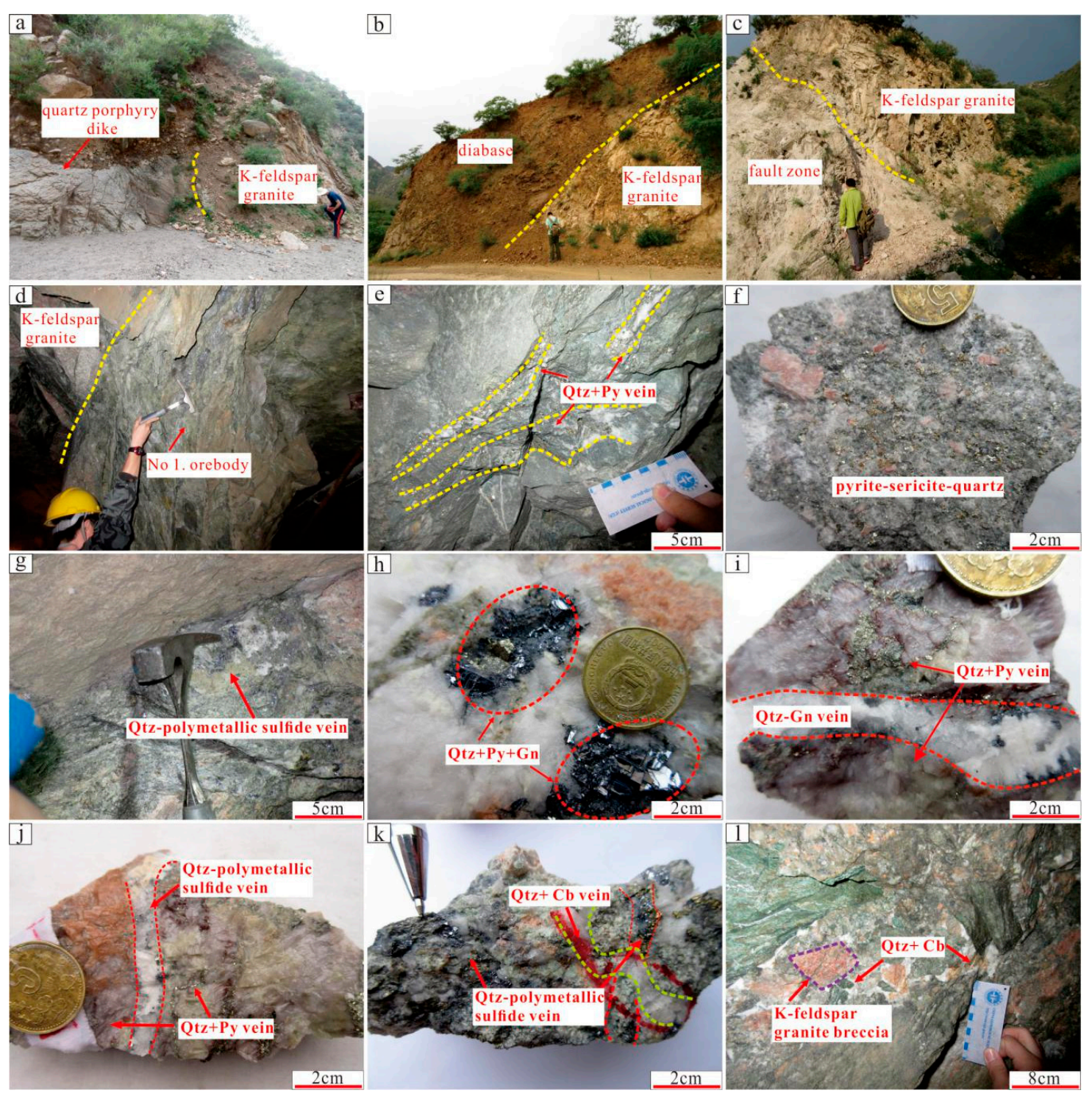

Figure 4. Representative photographs of field features and hand specimens. (a) The quartz porphyry intruded into the K-feldspar granite; (b) the contact zone between diabase and K-feldspar granite; (c) the contact zone between fault zone and K-feldspar granite; (d) the number 1 orebody at level $194 \mathrm{~m}$; (e) Quartz-pyrite vein in an early-stage gneiss; (f) early-stage pyrite-sericite-quartz altered rocks; (g) middle-stage quartz-polymetallic sulfide vein in gneiss; (h) middle-stage quartz, pyrite, and galena in altered K-feldspar granite; (i) early-stage quartz-pyrite vein cut by middle-stage quartz-galena vein; (j) early-stage quartz-pyrite vein cut by middle-stage quartz-polymetallic sulfide vein; (k) middle-stage quartz-polymetallic sulfide vein cut by late-stage quartz-carbonate vein; (l) and hydrothermal breccia and late-stage quartz-carbonate vein. Mineral abbreviations: Py, pyrite; Gn, galena; Qtz, quartz; and $\mathrm{Cb}$, carbonate. 

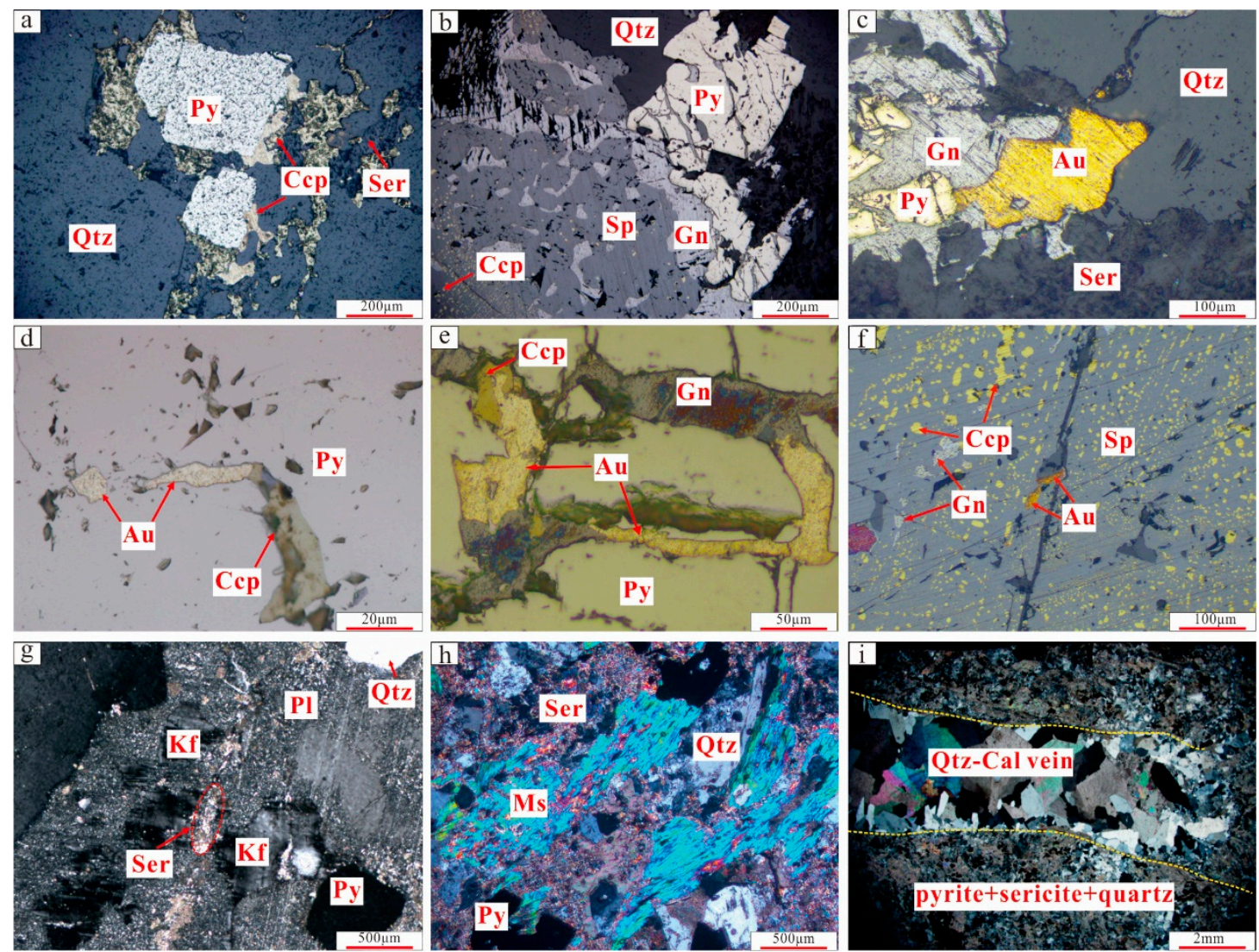

Figure 5. Photomicrographs showing the mineral assemblages of ores, the occurrence of gold (Figure 5a-f), and the alteration (Figure 5g-i) marking different stages in the Liyuan gold deposit. (a) Early-stage pyrite cemented by middle-stage chalcopyrite; (b) middle-stage galena and sphalerite replacing early-stage pyrite; (c) pyrite replaced by galena and coarse-grained gold occurring between quartz, pyrite, and galena; (d) and (f) gold and chalcopyrite occurring as inclusions in pyrite and sphalerite crystals, suggesting a close relationship; (e) gold occurring in the microfissures of pyrite; (g) K-feldspathization and sericitization of plagioclase in the early stage; (h) pyrite + sericite + silica alteration; and (i) late-stage quartz and calcite vein. Mineral abbreviations: Py, pyrite; Gn, galena; Ccp, chalcopyrite; Sp, sphalerite; Au, gold; Qtz, quartz; Ser, sericite; Ms, muscovite; Kf, K-feldspar; and Cal, calcite.

Pyrite was the dominant sulfide mineral in the Liyuan gold deposit. Five types of pyrite were identified, based on the metasomatic relationship and crystal textures (Figure 6). In the early stage, Py1 to Py3 all occurred in pyrite-sericite-quartz rocks or quartz-pyrite veins (Figure 6a-c). Py1 occurred as coarse-grained pyrite with many mineral inclusions (Figure 6a). Py2 was generally medium-grained and euhedral pyrite with minor/no mineral inclusions (Figure 6b). Py3 showed a zoning structure and different rims (Py3-a) and cores (Py3-b) (Figure 6c). In the middle stage, Py4 to Py5 occurred in quartz-polymetallic sulfide veins. Py4 was characterized by a cataclastic texture and microfractures (Figure 6d,e). Py5 exhibited subhedral crystals and a metasomatic texture (Figure 6f). 

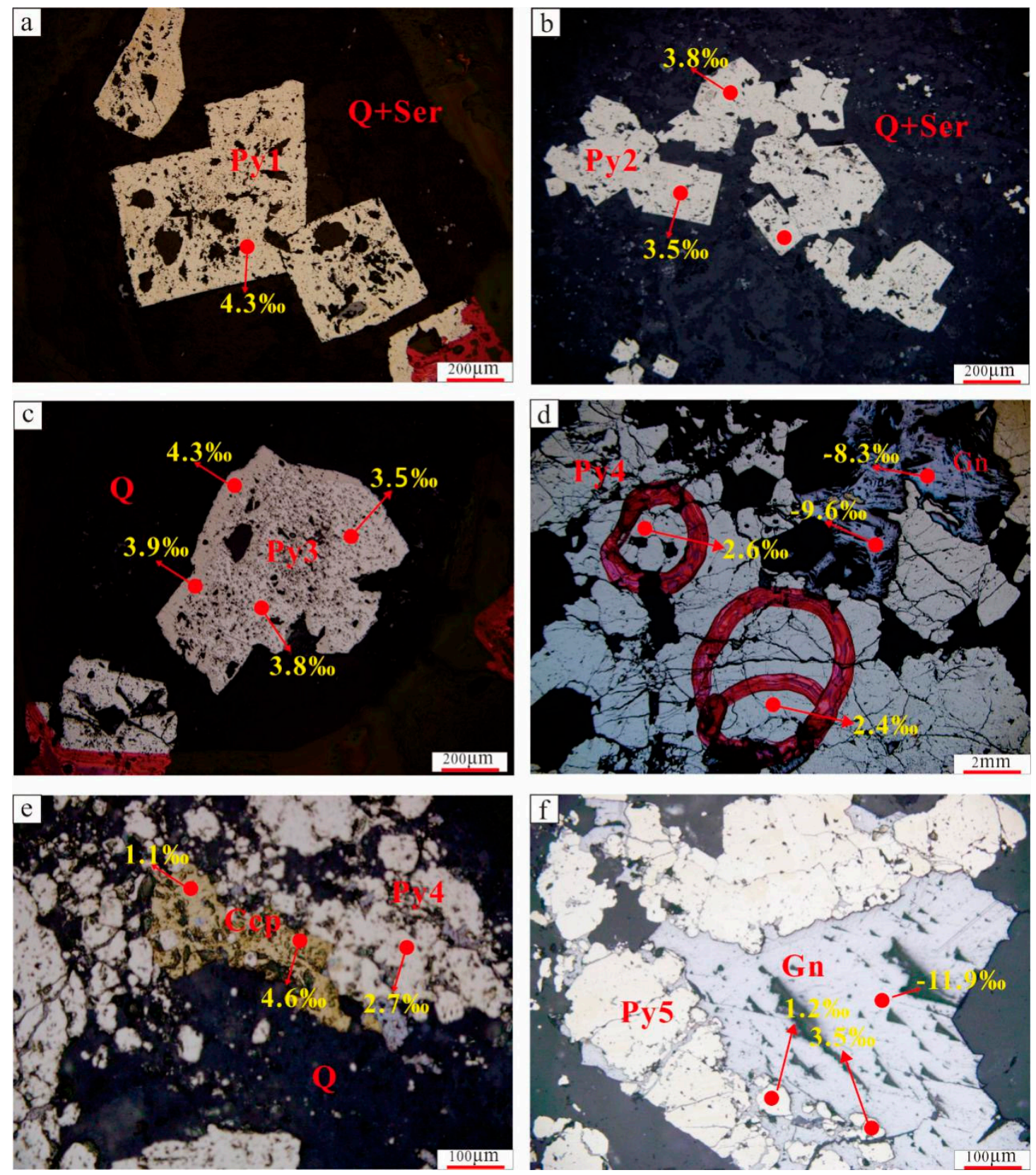

Figure 6. Reflected light photomicrographs showing sulfide minerals in the Liyuan gold deposit. (a) Coarse-grained pyrite (Py1) with rich mineral inclusions in the early-stage pyrite-sericite-quartz rocks; (b) medium-grained and euhedral pyrite (Py2) with minor/no mineral inclusions in the early-stage pyrite-sericite-quartz rocks; (c) pyrite (Py3) showing distinct zoning structure with an inclusion-rich core overgrown by a clean rim; (d) middle-stage pyrite (Py4) showing cataclastic texture and microfractures; (e) characteristics of a paragenetic relationship between fragmented pyrite (Py4) and chalcopyrite; and (f) Pyrite (Py5) replaced by galena in the middle stage. Mineral abbreviations: Py, pyrite; Gn, galena; Ccp, chalcopyrite; Qtz, quartz; Ser, sericite; and XX\%o, the value of $\delta^{34} \mathrm{~S}$.

\subsection{Hydrothermal Alteration and Mineralization Stages}

Hydrothermal alteration in the Liyuan gold deposit is represented by silicification, K-feldspathization, sericitization, chloritization, and carbonation (Figure $5 \mathrm{~g}-\mathrm{i}$ ). There were two forms of silicification: One form occurred as quartz-pyrite, quartz-polymetallic sulfide, and quartz-carbonate veins (Figure $4 \mathrm{e}, \mathrm{i}, \mathrm{j}$ ), and the other form occurred as fine-grained quartz and coexisted with sericite in the altered rocks (Figure $4 \mathrm{f}$ ). Sericitization mainly occurred as scaly aggregates, which was the 
result of cementing by plagioclase (Figure 5g,h). Pyrite, together with the above alterations, formed pyrite-sericite-quartz altered rocks, which were important signs for ore prospecting. Carbonation was poorly developed during the late stage of the hydrothermal system, and mainly produced calcite and ankerite (Figure 4j,1 and Figure 5i).

Field evidence, petrographic observations, mineral assemblages, and crosscutting relationships indicated three stages of hydrothermal activity during the formation of the Liyuan gold deposit. The mineralogy and associated wall rock alteration of the three main paragenetic stages are briefly summarized below (Figure 7).

\subsubsection{Quartz-Pyrite Stage (Early Stage)}

The quartz-pyrite stage is responsible for the formation of early mineralization and is marked by pyrite-sericite-quartz altered rocks or quartz-pyrite veins (Figure 4e,f). Ore minerals dominantly consisted of pyrite, and showed sparsely disseminated coarse to medium-grained and euhedral to subhedral crystals (Figures $4 \mathrm{f}$ and $6 \mathrm{a}-\mathrm{c}$ ). Pyrite was commonly cemented by later sulfides (Figures 4i, 5a-c and 6f). Quartz and sericite were the main gangue minerals (Figures $4 \mathrm{f}$ and $5 \mathrm{a}-\mathrm{c}$ ). Quartz during this stage was mostly milky white to smoky gray and medium grained (Figure 4e). Sericite was intergrown with pyrite and quartz, and showed scaly aggregates. A small amount of gold occurred as free gold in pyrite.

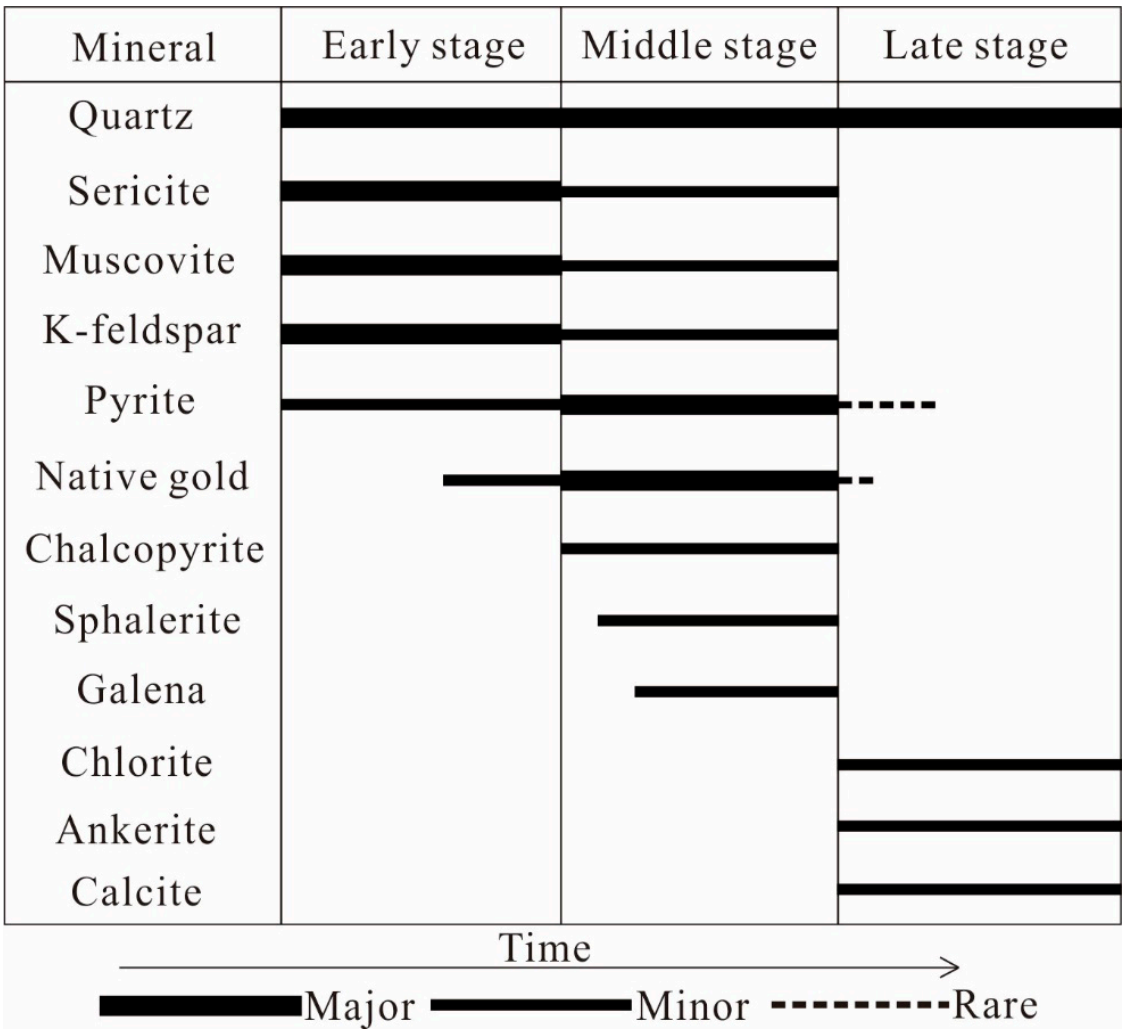

Figure 7. Paragenetic sequence for major minerals of the Liyuan gold deposit.

\subsubsection{Quartz-Polymetallic Sulfide Stage (Middle Stage)}

This stage corresponded to the formation of the major gold mineralization and was marked by quartz-polymetallic sulfide veins (Figure $4 \mathrm{~g}-\mathrm{k}$ ). Ore minerals included pyrite, sphalerite, galena, and chalcopyrite (Figure 4g-h). Pyrite was the most abundant sulfide and mainly occurred as euhedral crystals or as subhedral aggregates (Figure 4h,j and Figure $6 \mathrm{~d}-\mathrm{f}$ ). Pyrite was replaced by sphalerite and galena was commonly observed in this stage, indicating that these sulfides formed later than pyrite (Figure 4i,j). Quartz was the main gangue mineral, appearing milky white to smoky gray and fine 
grained (Figure $4 \mathrm{~h}-\mathrm{j}$ ). Most gold occurs as free gold and electrum in pyrite (Figure $5 \mathrm{~d}$,e), with minor amounts disseminated in quartz, sphalerite, and galena (Figure $5 \mathrm{c}, \mathrm{f})$.

\subsubsection{Quartz-Carbonate Stage (Late Stage)}

This stage was the late stage of hydrothermal activity and was marked by calcite, ankerite, and quartz (Figure $4 \mathrm{k}, 1)$. The hydrothermal carbonate minerals only occurred in the late stage, and their contents were relatively low (less than 5\%). Almost no pyrite and gold were deposited in this stage. The quartz-carbonate veins crosscut the quartz-polymetallic sulfide veins or the cement hydrothermally altered breccias, which developed during the former stages and filled the fractures of altered rocks (Figure $4 k, 1$ and Figure 5i). These relationships indicated that the quartz-carbonate veins formed during the waning stages of the hydrothermal system.

\section{Samples and Methods}

\subsection{Fluid Inclusion Microthermometry}

To better understand the origin and evolution of the hydrothermal fluids involved in the formation of the Liyuan gold deposit, 45 samples $(+608 \mathrm{~m},+478 \mathrm{~m},+284 \mathrm{~m},+254 \mathrm{~m}$, and $+194 \mathrm{~m})$ representing the stages of mineralization from the No. 1 orebody were collected from this deposit. A detailed observation of FIs in quartz was conducted on 45 doubly polished thin sections. Fluid inclusion petrography mainly involved careful observation of the shapes, vapor/liquid ratios, genetic and composition types, and characteristics of spatial distribution. Based on detailed petrography, nine representative samples (early stage, 3; middle stage, 5; and late stage, 1) from the No. 1 orebody were selected for microthermometric measurements and laser Raman spectroscopy analyses. Samples LYB-90 (+254 m), LYB-106 (+194 m), and LYB-116 (+194 m) were from the early stage, samples LYB-23 (+254 m), LYB-27-2 (+284 m), LYB-27-3 (+284 m), LYB-84 (+254 m), and LYB-88 (+254 m) were from the middle stage, and sample LYB-112 (+194 m) was from the late stage.

Microthermometric measurements were carried out using a Linkam THM600 heating-freezing stage with a measured temperature range from $-180-600^{\circ} \mathrm{C}$ at the Fluid Inclusion Laboratory, China University of Geosciences (Beijing). The accuracy of measurements was ensured by calibration at $-56.6{ }^{\circ} \mathrm{C}$ and $0{ }^{\circ} \mathrm{C}$ using synthetic FI standards and pure water. The heating/freezing rate was $0.1-0.2{ }^{\circ} \mathrm{C} / \mathrm{min}$ near phase transformations. Errors were approximately $\pm 0.2{ }^{\circ} \mathrm{C}$ for final ice melting temperatures and $\pm 5^{\circ} \mathrm{C}$ for homogenization temperatures. Detailed analytical procedures followed those reported in previous studies $[43,44]$.

Five types of temperature were observed: Final melting temperature of clathrate $\left(\mathrm{T}_{\mathrm{m} \text {-cla }}\right)$, final melting temperature of solid $\mathrm{CO}_{2}\left(\mathrm{~T}_{\mathrm{m}-\mathrm{CO} 2}\right)$, final melting temperature of water ice $\left(\mathrm{T}_{\mathrm{m} \text {-ice }}\right)$, homogenization temperature of $\mathrm{CO}_{2}\left(\mathrm{~T}_{\mathrm{h}-\mathrm{CO} 2}\right)$, and total homogenization temperature $\left(\mathrm{T}_{\mathrm{h}}\right)$. The salinities of aqueous and aqueous-carbonic FIs were calculated using $\mathrm{T}_{\mathrm{m} \text {-ice }}[45]$ and $\mathrm{T}_{\mathrm{m} \text {-cla }}$ [46], respectively. Using the Flincor computer software [47], densities could be estimated.

Laser Raman spectroscopic analysis of the FIs was carried out on a LABHR-VIS LabRAM HR800 microspectrometer at the Beijing Geological Research Institute of Nuclear Industry. The wavelength was $532 \mathrm{~nm}$ for the argon ion laser. The scanning range for spectra lay between 100 and $4000 \mathrm{~cm}^{-1}$, with an accumulation time of $10 \mathrm{~s}$ for each scan and a spectral resolution of $1-2 \mathrm{~cm}^{-1}$.

\subsection{H-O-S Isotope Analysis}

Five quartz samples from different stages of the No. 1 orebody were selected under the microscope to analyze mineral oxygen and FI hydrogen, including samples LYC-27, LYC-31, and LYC-51 from the early stage, samples LYC-13-1 from the middle stage, and sample LYC-44 from the late stage. Individual quartz grains, $0.25-0.4 \mathrm{~mm}$ in size, were prepared by careful handpicking under a binocular microscope, followed by cleaning in doubly distilled water. These samples were prepared in the Analytical Laboratory Beijing Research Institute of Uranium Geology by a technique modified from 
Clayton and Mayeda [48]. Oxygen was liberated for isotopic analysis using $\mathrm{BrF}_{5}$, and the resultant oxygen reacted with graphite rods to generate $\mathrm{CO}_{2}$, the isotopic composition of which was determined using a Finnigan MAT-253 mass spectrometer.

Hydrogen isotope analyses of FIs were carried out on splits of the samples analyzed for oxygen isotopes using the following procedure. Aliquots were enclosed in a Mo tube, dried for $\sim 4 \mathrm{~h}$ at $105^{\circ} \mathrm{C}$ in a vacuum $\left(10^{-3} \mathrm{mbar}\right)$ to eliminate adsorbed air moisture and then heated to $\sim 1400{ }^{\circ} \mathrm{C}$ in an induction oven for $45 \mathrm{~min}$, or until the sample stopped emitting gas. Noncondensable gases, $\mathrm{CO}_{2}$, and any $\mathrm{SO}_{2}$ were separated cryogenically. The resultant $\mathrm{H}_{2} \mathrm{O}$ was reduced to $\mathrm{H}_{2}$ by hot chromium at $800{ }^{\circ} \mathrm{C}$. The hydrogen was analyzed using a Finnigan MAT-253 mass spectrometer at the Analytical Laboratory of the Beijing Research Institute of Uranium Geology, Beijing, China. The results were reported in per mil notation relative to Vienna standard mean ocean water (V-SMOW), with analytical precisions of $\pm 0.2 \%$ o $(2 \sigma)$ for $\delta^{18} \mathrm{O}$ and $\pm 1 \%$ o $(2 \sigma)$ for $\delta \mathrm{D}$.

For the in situ sulfur isotope analyses, four representative samples (LYB-27-2, LYB-27-3, LYB-106, and LYB-116) were chosen from the early and middle stages in the No. 1 orebody of the Liyuan gold deposit. The analysis was carried out using LA-MC-ICP-MS at the State Key Laboratory of Geological Processes and Mineral Resources (GPMR), China University of Geosciences (Wuhan) following the methods of Zhu et al. [49]; a $193 \mathrm{~nm}$ New Wave ArF Excimer laser was coupled with a Neptune Plus multicollector ICP-MS (MC-ICP-MS) instrument. Helium gas was used to transport the ablated materials into the plasma with a gas flow of $0.7 \mathrm{~L} / \mathrm{min}$ [49]. Sample gas (argon, $0.85 \mathrm{~L} / \mathrm{min}$ ) was mixed with the carrier gas in a cyclone coaxial mixer before being transported into the ICP torch. The energy fluence of the laser was approximately $3 \mathrm{~J} / \mathrm{cm}^{2}$. The integration time for the isotope was $1.023 \mathrm{~s}$, and the MC-ICP-MS was set to medium-resolution mode to separate polyatomic interferences (e.g., ${ }^{16} \mathrm{O}_{2}^{+}$, ${ }^{1} \mathrm{H}^{32} \mathrm{~S}^{+},{ }^{16} \mathrm{O}^{17} \mathrm{O}^{+},{ }^{1} \mathrm{H}^{16} \mathrm{O}^{16} \mathrm{O}^{+}$, and ${ }^{16} \mathrm{O}^{18} \mathrm{O}^{+}$) from ${ }^{32} \mathrm{~S}$ and ${ }^{33} \mathrm{~S}$ to ${ }^{34} \mathrm{~S}$ [49]. The diameter was $33 \mu \mathrm{m}$ with a laser repletion rate of $8 \mathrm{~Hz}$ for single spot analysis. The low background of less than $70 \mathrm{mV}$ on ${ }^{32} \mathrm{~S}$ compared to approximately $20 \mathrm{~V}$ of signal (for pyrite samples) and the fast "washout" time of $25 \mathrm{~s}$ allowed a high sample throughput. The sample-standard bracketing approach was used to determine the $\delta^{34} S$ values of samples throughout the MC-ICP-MS analytical sessions [50]. The detailed analytical procedures and conditions followed those of Zhu et al. [49,50].

\section{Results}

\subsection{Fluid Inclusion Petrography}

The majority of FIs occurred in clusters or as isolated inclusions in crystal cores, suggesting that they were possibly primary in origin. Less commonly, inclusions occurred within microfractures that cut across all the phases (secondary inclusions) or along microfractures constrained by the boundaries of the host crystals (pseudosecondary inclusions). To investigate the ore deposition, we focused on the FIs hosted in the quartz of all stages. All FIs measured in this study were primary inclusions. Based on their characteristics at room temperature and their microthermometric behaviors, three different types of FIs were identified: $\mathrm{CO}_{2}$-aqueous FIs (type I), pure $\mathrm{CO}_{2}$ FIs (type II), and aqueous FIs (type III) (Figure 8). The classification in this paper is also in accordance with those of Ju et al. [21] and Ma et al. [23].

\subsubsection{Type I}

Type I inclusions consisted of $\mathrm{H}_{2} \mathrm{O}$ and $\mathrm{CO}_{2}$ phases with 10-80 vol.\% carbonic phase. They could be divided into two subtypes: type $\mathrm{I}_{\mathrm{a}}\left(\mathrm{V}_{\mathrm{CO} 2}+\mathrm{L}_{\mathrm{CO} 2} \leq 50 \%\right)$ and type $\mathrm{I}_{\mathrm{b}}\left(\mathrm{V}_{\mathrm{CO} 2}+\mathrm{L}_{\mathrm{CO} 2}>50 \%\right)$ at room temperature $\left(25^{\circ} \mathrm{C}\right)$ (Figure $\left.8 \mathrm{a}-\mathrm{c}, \mathrm{f}-\mathrm{h}\right)$. Type I inclusions commonly showed elliptical or irregular shapes that range from 4-24 $\mu \mathrm{m}$ in size. They were abundant in quartz grains during the early and middle stages, occurring in isolation or in clusters. In some cases, type I FIs coexisted with type II and type III fluid inclusions within the quartz grain (Figure $8 \mathrm{a}, \mathrm{c}, \mathrm{f}, \mathrm{g}$ ). This phenomenon likely indicates that immiscible fluid phases were trapped at the same time [51,52], and this hypothesis is discussed below. 

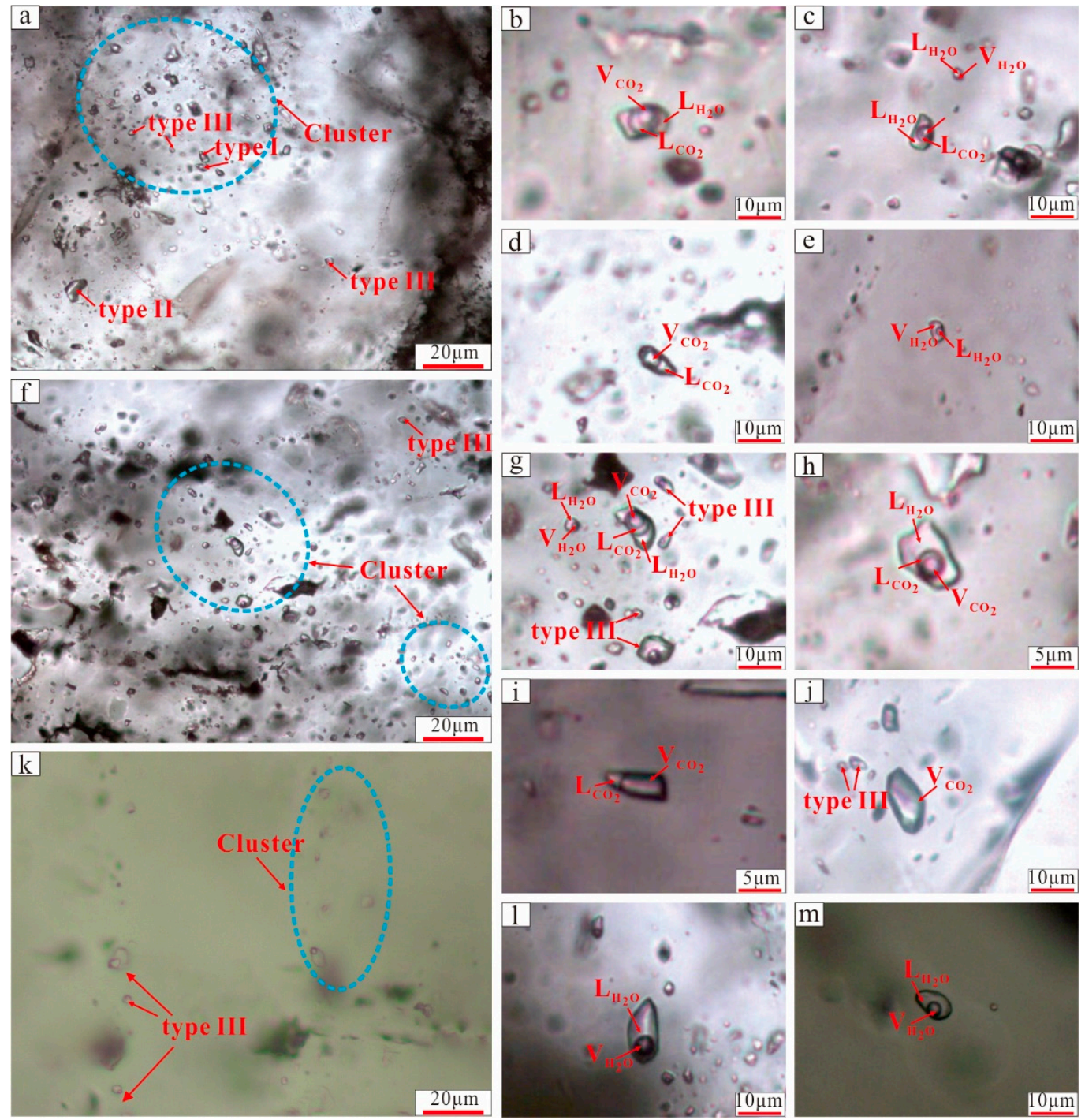

Figure 8. Photomicrographs of various types of fluid inclusions in the Liyuan gold deposit. (a) Coexistence of different fluid inclusions as clusters or isolated in the early stage; (b) typical vapor-rich type I FIs, (c) typical liquid-rich type I FIs, (d) type II FIs, and (e) type III FIs in the early stage; (f) coexistence of types I, II, and III FIs as isolated inclusions or clusters in the middle stage; (g) coexistence of vapor-rich type I and type III FIs in the middle stage; (h) isolated liquid-rich type I FIs in the middle stage; $(\mathbf{i}, \mathbf{j})$ two phases and mono-phase type II FIs in the middle stage; $(\mathbf{k})$ type III FIs as clusters in the late stage; and $(\mathbf{l}, \mathbf{m})$ type III FIs in the middle stage and late stage, respectively. Abbreviations: $\mathrm{V}_{\mathrm{H}_{2} \mathrm{O}}$, aqueous vapor phase; $\mathrm{L}_{\mathrm{H}_{2} \mathrm{O}}$, aqueous liquid phase; $\mathrm{V}_{\mathrm{CO}_{2}}$, carbonic vapor phase; and $\mathrm{L}_{\mathrm{CO}_{2}}$, carbonic liquid phase.

\subsubsection{Type II}

Type II inclusions were composed of pure carbonic fluid at room temperature $\left(25^{\circ} \mathrm{C}\right)$ containing a single phase $\left(\mathrm{V}_{\mathrm{CO}_{2}}\right.$ or $\left.\mathrm{L}_{\mathrm{CO}_{2}}\right)$ and two phases $\left(\mathrm{V}_{\mathrm{CO}_{2}}+\mathrm{L}_{\mathrm{CO}_{2}}\right)$ (Figure $\left.8 \mathrm{~d}, \mathrm{i}, \mathrm{j}\right)$. Type II inclusions were commonly dark with elliptical shapes or negative crystals, ranging from 5-12 $\mu \mathrm{m}$ in size. They mostly coexisted with type I inclusions in the early and middle stages.

\subsubsection{Type III}

Type III inclusions were two-phase $\left(\mathrm{V}_{\mathrm{H}_{2} \mathrm{O}}+\mathrm{L}_{\mathrm{H}_{2} \mathrm{O}}\right)$ liquid-rich FIs at room temperature $\left(25^{\circ} \mathrm{C}\right)$ (Figure $8 \mathrm{a}, \mathrm{e}-\mathrm{g}, \mathrm{k}-\mathrm{m}$ ). These inclusions usually showed volumetric proportions of the liquid phase from $5-30 \%$. They had a variety of shapes, including elliptical, negative crystal, and irregular, and ranged 
from 2-17 $\mu \mathrm{m}$ in size. Type III inclusions appeared to be the most abundant FIs in all mineralization stages and commonly coexisted with type I and II inclusions in the middle stage (Figure 8f,g,j). In general, primary type III FIs occurred as isolated inclusions or clusters (Figure $8 \mathrm{a}, \mathrm{e}-\mathrm{g}, \mathrm{k}-\mathrm{m}$ ), whereas secondary type III FIs aligned along microfractures.

\subsection{Microthermometry}

\subsubsection{Early Stage}

Type III fluid inclusions were dominant in the early-stage quartz, with some type I and type II FIs. The $\mathrm{T}_{\mathrm{m}-\mathrm{CO}_{2}}$ in type I FIs ranges from $-61.5^{\circ} \mathrm{C}$ to $-57.0^{\circ} \mathrm{C}$ (Table 1), values that are equal to or slightly lower than the triple point of pure $\mathrm{CO}_{2}\left(-56.6^{\circ} \mathrm{C}\right)$, indicating the presence of trace amounts of $\mathrm{CH}_{4}$ or other gases [52]. The $\mathrm{T}_{\mathrm{m} \text {-cla }}$ occurred in the interval from $4.7-8.3{ }^{\circ} \mathrm{C}$, with corresponding salinities ranging from 3.3-9.4 wt.\% $\mathrm{NaCl}$ equivalent (Figure $9 \mathrm{~b}$, Table 1). The carbonic phase partially homogenizes to liquid between $24.4^{\circ} \mathrm{C}$ and $30.9^{\circ} \mathrm{C}$. Total homogenization was observed at temperatures from $245-364{ }^{\circ} \mathrm{C}$, generally homogenizing to liquid (the quantity was 19) and vapor (the quantity was 6 ) (Figure 9a, Table 1). The calculated $\mathrm{CO}_{2}$ densities and bulk densities ranged from $0.65-0.73 \mathrm{~g} / \mathrm{cm}^{3}$ and $0.65-0.88 \mathrm{~g} / \mathrm{cm}^{3}$, respectively (Table 1 ).
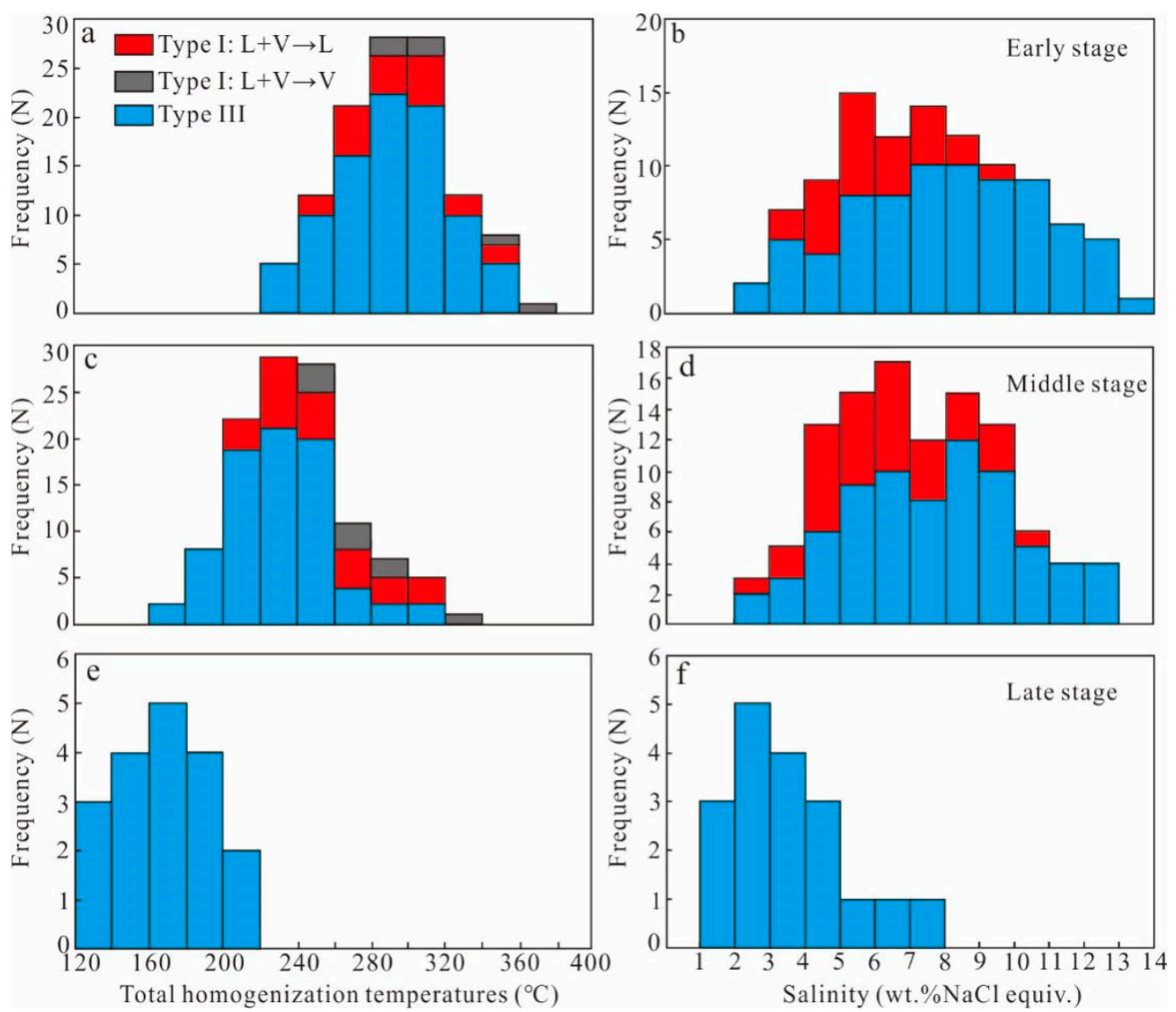

Figure 9. Frequency histograms of total homogenization temperatures $\left(T_{h}\right)$ and salinities of fluid inclusions from different stages of the Liyuan gold deposit. Early stage (a,b); middle stage (c,d); and late stage $(\mathbf{e}, \mathbf{f})$.

For type II FIs, the $\mathrm{T}_{\mathrm{m}-\mathrm{CO}_{2}}$ ranged from $-58.8^{\circ} \mathrm{C}$ to $-57.0^{\circ} \mathrm{C}$ (Table 1 ), suggesting that the dominant component was $\mathrm{CO}_{2}$. $\mathrm{CO}_{2}$ was generally homogenized to the liquid phase, and the $\mathrm{T}_{\mathrm{h}-\mathrm{CO}_{2}}$ lies between $27.7^{\circ} \mathrm{C}$ and $29.1^{\circ} \mathrm{C}$ with corresponding densities of $0.64-0.71 \mathrm{~g} / \mathrm{cm}^{3}$ (Table 1 ). 
Table 1. Microthermometric data for fluid inclusions from the different stages analyzed in this study.

\begin{tabular}{|c|c|c|c|c|c|c|c|c|c|c|c|}
\hline Stage & Type & Number & Size $/ \mu \mathrm{m}$ & $\mathrm{T}_{\mathrm{m}-\mathrm{CO}_{2}} /{ }^{\circ} \mathrm{C}$ & $\mathrm{T}_{\mathrm{m}-\mathrm{cla}} /{ }^{\circ} \mathrm{C}$ & $\mathrm{T}_{\mathrm{h}-\mathrm{CO}_{2}} /{ }^{\circ} \mathrm{C}$ & $\mathrm{T}_{\text {m-ice }} /{ }^{\circ} \mathrm{C}$ & $\mathrm{T}_{\mathrm{h}} /{ }^{\circ} \mathrm{C}$ & $\begin{array}{l}\text { Salinity/wt.\% } \\
\mathrm{NaCl} \text { equiv. }\end{array}$ & $\begin{array}{c}\mathrm{CO}_{2} \text { Density } \\
\left(\mathrm{g} / \mathrm{cm}^{3}\right)\end{array}$ & $\begin{array}{c}\text { Bulk Density } \\
\left(\mathrm{g} / \mathrm{cm}^{3}\right)\end{array}$ \\
\hline \multirow{3}{*}{ Early } & I & 25 & $4-16$ & -61.5 to -57.0 & $4.7-8.3$ & $24.4-30.9$ & - & $245-364(\mathrm{~L} / \mathrm{V})$ & $3.3-9.4$ & $0.65-0.73$ & $0.65-0.88$ \\
\hline & II & 8 & 5-14 & -58.8 to -57.0 & - & $27.7-29.1$ & - & - & - & $0.64-0.71$ & - \\
\hline & III & 89 & $3-12$ & - & - & - & -9.8 to -1.7 & $233-355$ & $2.9-13.7$ & - & $0.69-0.93$ \\
\hline \multirow{3}{*}{ Middle } & I & 36 & $4-24$ & -60.1 to -57.3 & $4.2-8.8$ & $25.3-30.3$ & - & $213-326(\mathrm{~L} / \mathrm{V})$ & $2.4-10.2$ & $0.66-0.72$ & $0.72-0.91$ \\
\hline & II & 10 & $5-12$ & -59.2 to -57.4 & - & $25.0-30.5$ & - & - & - & $0.60-0.72$ & - \\
\hline & III & 78 & $3-12$ & - & - & - & -8.5 to -1.3 & $170-318$ & $2.2-12.3$ & - & $0.78-0.95$ \\
\hline Late & III & 18 & $3-8$ & - & - & - & -4.4 to -0.9 & $120-216$ & $1.6-7.1$ & - & $0.85-0.94$ \\
\hline
\end{tabular}

Note: $\mathrm{N}$, number of measured fluid inclusion; $\mathrm{T}_{\mathrm{m}-\mathrm{CO}_{2}}$, final melting temperature of solid $\mathrm{CO}_{2} ; \mathrm{T}_{\mathrm{m} \text {-cla }}$, final melting temperature of clathrate; $\mathrm{T}_{\mathrm{h}-\mathrm{CO}_{2}}$, homogenization temperature of $\mathrm{CO}_{2}$;

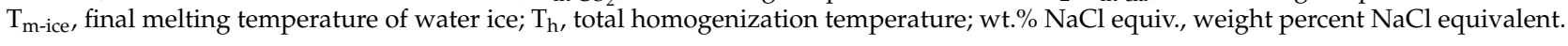


Type III inclusions yielded $\mathrm{T}_{\mathrm{h}}$ between $233-355{ }^{\circ} \mathrm{C}$ and $\mathrm{T}_{\mathrm{m} \text {-ice }}$ from $-9.8{ }^{\circ} \mathrm{C}$ to $-1.7{ }^{\circ} \mathrm{C}$, with corresponding salinities from $2.9-13.7 \mathrm{wt} . \% \mathrm{NaCl}$ equivalent (Figure 9a,b, Table 1). The calculated bulk densities ranged from $0.69-0.93 \mathrm{~g} / \mathrm{cm}^{3}$ (Table 1).

\subsubsection{Middle Stage}

The middle stage also contained all the types of inclusions, with type I and type III FIs being the most abundant. The $\mathrm{T}_{\mathrm{m}-\mathrm{CO}_{2}}$ values in type I FIs ranged from $-60.1^{\circ} \mathrm{C}$ to $-57.3^{\circ} \mathrm{C}$ (Table 1 ), which were slightly lower than the triple point of pure $\mathrm{CO}_{2}\left(-56.6^{\circ} \mathrm{C}\right)$, indicating that the carbonic phase was mainly composed of $\mathrm{CO}_{2}$ and minor other gas components. The $\mathrm{T}_{\mathrm{m} \text {-cla }}$ occurs from $4.2-8.8^{\circ} \mathrm{C}$, with corresponding salinities from $2.4-10.2 \mathrm{wt} . \% \mathrm{NaCl}$ equivalent (Figure $9 \mathrm{~d}$, Table 1). $\mathrm{CO}_{2}$ was generally homogenized to the liquid phase, and the $\mathrm{T}_{\mathrm{h}-\mathrm{CO}_{2}}$ ranged between $25.3-30.3{ }^{\circ} \mathrm{C}$ (Table 1 ). The $T_{h}$ values were measured at temperatures from $213-326^{\circ} \mathrm{C}$, generally homogenizing to liquid (the quantity was 27) and vapor (the quantity was 9) (Figure 9c, Table 1). The calculated $\mathrm{CO}_{2}$ densities and bulk densities ranged from $0.66-0.72 \mathrm{~g} / \mathrm{cm}^{3}$ and $0.72-0.91 \mathrm{~g} / \mathrm{cm}^{3}$, respectively (Table 1 ).

For type II FIs, the $\mathrm{T}_{\mathrm{m}-\mathrm{CO}_{2}}$ values ranged from $-59.2{ }^{\circ} \mathrm{C}$ to $-57.4{ }^{\circ} \mathrm{C}$, suggesting that the dominant component was $\mathrm{CO}_{2}$ with trace amounts of $\mathrm{CH}_{4}$ or other gases [53]. $\mathrm{CO}_{2}$ generally homogenized to the liquid phase, and the $\mathrm{T}_{\mathrm{h}-\mathrm{CO}_{2}}$ varied from $25-30.5{ }^{\circ} \mathrm{C}$, with calculated densities of $0.6-0.72 \mathrm{~g} / \mathrm{cm}^{3}$ (Table 1).

Type III inclusions exhibited $\mathrm{T}_{\mathrm{m} \text {-ice }}$ of $-8.5^{\circ} \mathrm{C}$ to $-1.3^{\circ} \mathrm{C}$, with corresponding salinities from 2.2-12.3 wt. $\% \mathrm{NaCl}$ equivalent (Figure $9 \mathrm{~d}$, Table 1). The $\mathrm{T}_{\mathrm{h}}$ values ranged from $170-318^{\circ} \mathrm{C}$ with bulk densities of $0.78-0.95 \mathrm{~g} / \mathrm{cm}^{3}$ (Figure 9c, Table 1).

\subsubsection{Late Stage}

Only type III inclusions were found in the late-stage quartz. The $\mathrm{T}_{\mathrm{m} \text {-ice }}$ ranged from $-4.4{ }^{\circ} \mathrm{C}$ to $-0.9^{\circ} \mathrm{C}$, with corresponding salinities from $1.6-7.1 \mathrm{wt} . \% \mathrm{NaCl}$ equivalent (Figure 9f, Table 1). Type III inclusions yielded $T_{h}$ values between $120-216{ }^{\circ} \mathrm{C}$, with bulk densities of $0.85 \mathrm{~g} / \mathrm{cm}^{3}$ to $0.94 \mathrm{~g} / \mathrm{cm}^{3}$ (Figure 9, Table 1).

\subsection{Laser Raman Spectroscopy}

Representative FIs were measured using laser Raman spectroscopy to determine gas compositions (Figure 10). In the early stage, the vapor phase of type I inclusions was dominated by $\mathrm{CO}_{2}$ and $\mathrm{H}_{2} \mathrm{O}$ (Figure 10a), while type II inclusions mainly contained $\mathrm{CO}_{2}$ (Figure 10b). In the middle stage, the vapor phase of type I inclusions mainly contained $\mathrm{CO}_{2}$ (Figure 10c), and some inclusions had additional $\mathrm{H}_{2} \mathrm{O}$ (Figure 10d). Type II inclusions in this stage were dominated by $\mathrm{CO}_{2}$ (Figure 10e). The vapor phase and liquid phase of type III inclusions were dominated by $\mathrm{H}_{2} \mathrm{O}$ (Figure 10f). The $\mathrm{T}_{\mathrm{m}-\mathrm{CO}_{2}}$ values in type I and III inclusions were slightly lower than $56.6{ }^{\circ} \mathrm{C}$, indicating trace amounts of $\mathrm{CH}_{4}$ or other gases [53]. This observation was consistent with the results of gas analyses of crushed FI groups (our unpublished data) and previous studies [21,23]. In this study, no $\mathrm{CH}_{4}, \mathrm{~N}_{2}, \mathrm{CO}$, or $\mathrm{H}_{2}$ is detected, which may suggest that the contents of these gases were below the detection limits. 

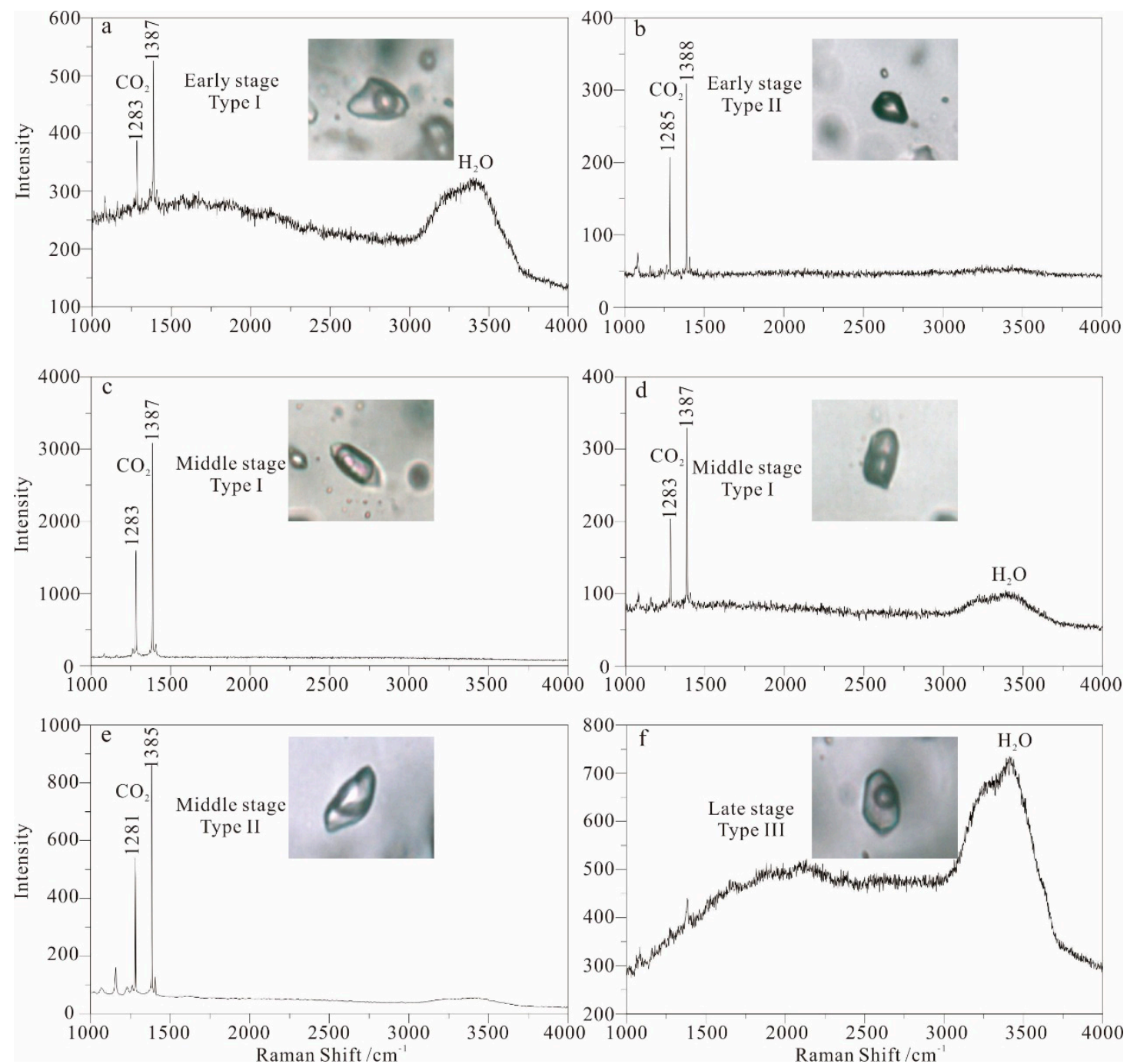

Figure 10. Representative Raman spectra of vapor bubbles for fluid inclusions from the Liyuan gold deposit. (a) $\mathrm{CO}_{2}$ and $\mathrm{H}_{2} \mathrm{O}$ spectra of vapor in early-stage type I inclusions; (b) $\mathrm{CO}_{2}$ spectra of vapor in early-stage type II inclusions; (c) $\mathrm{CO}_{2}$ spectra of vapor in middle-stage type I inclusions; (d) $\mathrm{CO}_{2}$ and $\mathrm{H}_{2} \mathrm{O}$ spectra of vapor in middle-stage type I inclusions; (e) $\mathrm{CO}_{2}$ spectra of vapor in middle-stage type II inclusions; and (f) $\mathrm{H}_{2} \mathrm{O}$ spectra of vapor in late-stage type III inclusions.

\subsection{Stable Isotope Studies}

\subsubsection{Hydrogen and Oxygen}

The hydrogen and oxygen isotope data obtained in this study are shown in Table 2. The $\delta \mathrm{D}$ values of the FIs in quartz from the Liyuan gold deposit varied from $-85.7 \%$ o to $-68.4 \%$, with an average value of $-76.5 \%$. The $\delta^{18} \mathrm{O}$ values were in the range of $14.2-17.9 \%$ o for quartz. The oxygen isotope compositions of hydrothermal waters were calculated using these $\delta^{18} \mathrm{O}$ values, $\mathrm{T}_{\mathrm{h}}$, and the fractionation formula of Clayton et al. [54]. The temperatures used for calculation were the mean values of every stage. The calculated oxygen isotope composition was characterized by $\delta^{18} \mathrm{O}_{\mathrm{H}_{2} \mathrm{O}}$ values of $0.3-10.7 \%$, with an average value of $6.5 \%$. 
Table 2. Hydrogen and oxygen isotope compositions for different stages analyzed in this study.

\begin{tabular}{ccccccc}
\hline Sample & Mineral & Stage & $\mathbf{T}_{\mathbf{h}}\left({ }^{\circ} \mathbf{C}\right)$ & $\boldsymbol{\delta}^{\mathbf{1 8}} \mathbf{O}_{\mathbf{V}-S M O W} \boldsymbol{\% o}$ & $\boldsymbol{\delta}^{\mathbf{1 8}} \mathbf{O}_{\mathbf{H}_{\mathbf{2}} \mathbf{O}} \mathbf{\% o}$ & $\boldsymbol{\delta D}_{\mathbf{H}_{\mathbf{2}} \mathbf{O}} \mathbf{\% o}$ \\
\hline LYC-27 & Quartz & I & 294 & 15.1 & 7.9 & -68.4 \\
LYC-31 & Quartz & I & 294 & 17.9 & 10.7 & -73.8 \\
LYC-51 & Quartz & I & 294 & 15.2 & 8.0 & -78.9 \\
LYC-13-1 & Quartz & II & 241 & 15.3 & 5.8 & -75.8 \\
LYC-44 & Quartz & III & 170 & 14.2 & 0.3 & -85.7 \\
\hline
\end{tabular}

$\mathrm{T}_{\mathrm{h}}$ is the mean total homogenization temperature for every stage.

\subsubsection{Sulfur Isotopes}

Sulfur isotope analyses were performed on four representative ore samples, and the results are shown in Table 3. In the early stage, the $\delta^{34} \mathrm{~S}$ values of Py1 and Py2 ranged from $3.4-4.3 \%$ and $2.9-3.8 \%$, respectively. The rims (Рy3-a) and cores (Py3-b) in Py3 had sulfur compositions of 3.9-4.3\%o and 3.5-3.8\%o, respectively. In the middle stage, Py4 had $\delta^{34} \mathrm{~S}$ values of $2.3-2.7 \%$, and Py5 ranges from $1.2-3.5 \%$. The $\delta^{34} \mathrm{~S}$ values of chalcopyrite ranged from $0.9-4.6 \%$, whereas all galena yielded negative $\delta^{34} \mathrm{~S}$ values of $-11.9 \%$ o to $-7.0 \%$ o.

Table 3. Sulfur isotope compositions (\%o) of sulfides analyzed in this study.

\begin{tabular}{|c|c|c|c|}
\hline Stage & Sample & Minerals & $\delta^{34} S$ \\
\hline \multirow{9}{*}{ Early } & LYB-116-1 & Py1 & 4.3 \\
\hline & LYB-116-2 & Py2 & 3.5 \\
\hline & LYB-116-3 & Py2 & 3.8 \\
\hline & LYB-116-4 & Py2 & 2.9 \\
\hline & LYB-116-5 & Py1 & 4.1 \\
\hline & LYB-106-1 & Рy3-a & 4.3 \\
\hline & LYB-106-2 & Py3-b & 3.5 \\
\hline & LYB-106-3 & Рy3-a & 3.9 \\
\hline & LYB-106-4 & Py3-b & 3.8 \\
\hline \multirow{18}{*}{ Middle } & LYB-106-5 & Py1 & 3.4 \\
\hline & LYB-27-2-1 & Py 4 & 2.4 \\
\hline & LYB-27-2-2 & Py4 & 2.6 \\
\hline & LYB-27-2-3 & Py4 & 2.7 \\
\hline & LYB-27-2-4 & Py5 & 3.3 \\
\hline & LYB-27-2-5 & Py5 & 2.2 \\
\hline & LYB-27-3-1 & Py 4 & 2.6 \\
\hline & LYB-27-3-2 & Py4 & 2.3 \\
\hline & LYB-27-3-3 & Py5 & 1.2 \\
\hline & LYB-27-3-4 & Py5 & 3.5 \\
\hline & LYB-27-2-10 & Chalcopyrite & 4.6 \\
\hline & LYB-27-2-11 & Chalcopyrite & 1.1 \\
\hline & LYB-27-2-12 & Chalcopyrite & 0.9 \\
\hline & LYB-27-2-6 & Galena & -10.8 \\
\hline & LYB-27-2-7 & Galena & -8.3 \\
\hline & LYB-27-2-8 & Galena & -9.6 \\
\hline & LYB-27-2-9 & Galena & -7 \\
\hline & LYB-27-3-5 & Galena & -11.9 \\
\hline
\end{tabular}




\section{Discussion}

\subsection{Fluid Immiscibility}

As described earlier, primary type I, type II, and type III FIs coexisted in a given cluster in quartz grains related to sulfides and gold in the Liyuan gold deposit. This distribution could have been the result of fluid mixing [55,56], post-entrapment modification [57-59], or fluid immiscibility by unmixing from a homogeneous $\mathrm{H}_{2} \mathrm{O}-\mathrm{CO}_{2}$ fluid $[51,52]$. Therefore, it is necessary to determine which process was related to the formation of the FIs associated with gold mineralization in the Liyuan gold deposit.

Post-entrapment modifications (such as leaking, stretching, and necking down [59]) may have led to the coexistence of type I and III FIs in the same sample. While a few quartz grains in the early and middle stages showed deformation, with secondary FIs along transgranular trails, all the FIs selected for microthermometry and laser Raman studies were primary in origin. These FIs commonly occurred in undeformed quartz grains with regular shapes, which therefore ruled out post-entrapment modifications.

Assuming that two different fluids mixed during the mineralization process, the mixing fluids would have produced an array of FIs with widely variable $T_{m}-\mathrm{CO}_{2}, T_{h}$, and salinities, indicating variable compositions and temperatures during entrapment $[60,61]$. However, type I and III FIs in this study showed uniform $\mathrm{T}_{\mathrm{h}}$ values and salinities, excluding the possibility of mixing between two separate fluids.

Fluid immiscibility is generally related to the deposition of gold and sulfides in many hydrothermal deposits, such as the Taishang [62], Xincheng [63], Jintingling [64], and Wang'ershan [65] gold deposits on the Jiaodong Peninsula, the Wenyu [66] gold deposit in Xiaoqinling, and the Jinshan gold deposit in the Jiangnan orogen [67]. Evidence for fluid immiscibility in the ore-related quartz from the early and middle stages, using the four criteria defined by Pichavant et al. [51], is listed as follows:

(1) Type I, II, and III FIs appeared in the same growth phase of quartz grains in the early and middle stages (Figure 8a-g) and could be considered to have been trapped contemporaneously.

(2) Type I FIs had variable degrees of filling from 10-80 vol. \% (Figure $8 \mathrm{a}, \mathrm{b}, \mathrm{g}, \mathrm{h}$ ) and showed two completely opposite modes of total homogenization. Type $\mathrm{I}_{\mathrm{a}}$ FIs generally homogenize to liquid $(\mathrm{L}+\mathrm{V} \rightarrow \mathrm{L})$, while type $\mathrm{I}_{\mathrm{b}}$ FIs with high $\mathrm{CO}_{2}$ phase(s) volume(s) commonly homogenized to vapor $(\mathrm{L}+\mathrm{V} \rightarrow \mathrm{V})$ (Figure $9 \mathrm{a}, \mathrm{c})$. The $\mathrm{T}_{\mathrm{h}}$ of the latter mode was slightly higher than that of the former mode (Figure 9a,c) because the purer end-member inclusions (with high $\mathrm{H}_{2} \mathrm{O}$ volumes) were trapped at lower temperatures, which was consistent with fluid immiscibility [68].

(3) Type I and II FIs had similar $\mathrm{T}_{\mathrm{h}-\mathrm{CO}_{2}}$ ranges, suggesting that the $\mathrm{CO}_{2}$-rich end-member may have been the result of unmixing of the $\mathrm{H}_{2} \mathrm{O}-\mathrm{CO}_{2}-\mathrm{NaCl}$ solution $[69,70]$.

(4) Type I and III FIs had similar $\mathrm{T}_{\mathrm{h}}$ ranges in the early and middle stages (Figure 9a,c and Figure 11). Type III FIs had slightly higher salinities (averages of 8.03 wt.\% and 7.56 wt. $\% \mathrm{NaCl}$ equivalent in the early and middle stages, respectively) than type I (averages of $5.83 \mathrm{wt} . \%$ and $6.26 \mathrm{wt} . \%$ $\mathrm{NaCl}$ equivalent in the early and middle stages, respectively) (Figure 11), and this observation was also consistent with phase separation, as salt preferentially fractionated into the aqueous phase [71,72].

In summary, we accordingly regarded fluid immiscibility as one of the possible mechanisms for gold mineralization in the Liyuan gold deposit. 


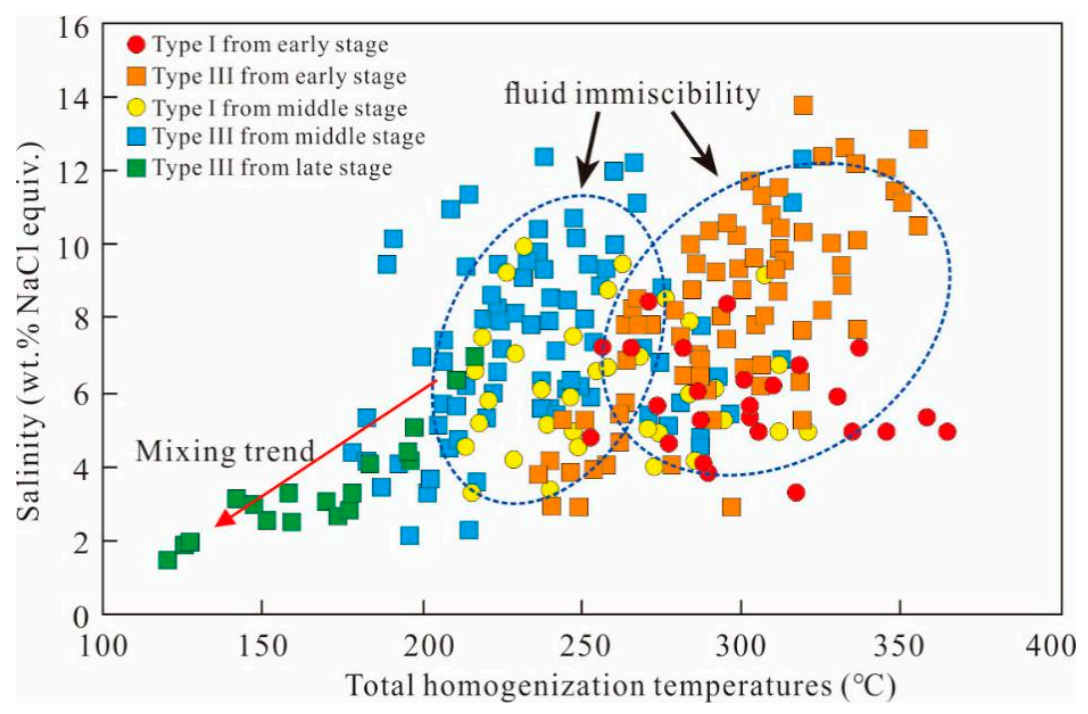

Figure 11. Total homogenization temperature versus salinity of fluid inclusions in the mineralization stages of the Liyuan gold deposit.

\subsection{Source and Evolution of Ore-Forming Fluids and Materials}

\subsubsection{Source of Ore-Forming Fluids and Materials}

Hydrogen and oxygen isotope analyses have been widely used to trace the origin and evolutionary history of paleohydrothermal fluids of magmatic, metamorphic, and meteoric origin [73,74]. In the early stage, the calculated $\delta^{18} \mathrm{O}_{\mathrm{H}_{2} \mathrm{O}}$ values for fluids in equilibrium with quartz varied from $7.9-10.7 \%$ o (mean value of $8.87 \%$ ), which accorded with fluids derived from magmatic sources (5-10\%o [75]). The $\delta \mathrm{D}$ values of quartz ranged from $-78.9 \%$ o to $-68.4 \%$, with a mean value of $-73.7 \%$, which was consistent with those of magmatic water $\left(-80 \%\right.$ o to $-50 \%$ o [76]). On a $\delta \mathrm{D}$ versus $\delta^{18} \mathrm{O}_{\mathrm{H}_{2} \mathrm{O}}$ diagram (Figure 12), the early-stage quartz samples mostly plotted within the magmatic water or metamorphic water fields, which indicated that the initial ore-forming fluids in this deposit were of magmatic or metamorphic origin. The timing of gold mineralization was approximately two billion years later than regional metamorphism, indicating that the inference of Paleoproterozoic metamorphism fluids in the Fuping region should be excluded. We therefore argued that the ore fluids were derived from magmatic origin. The calculated $\delta^{18} \mathrm{O}_{\mathrm{H}_{2} \mathrm{O}}$ and $\delta \mathrm{D}$ values in equilibrium with quartz during the middle stage were $5.8 \%$ o and $-75.8 \%$, respectively. Quartz of the middle-stage sample also plotted in the magmatic water field (Figure 12), which further suggested that fluids in this stage were of magmatic origin. In contrast to the early and middle stages, the measured $\delta^{18} \mathrm{O}_{\mathrm{H}_{2} \mathrm{O}}$ and $\delta \mathrm{D}$ values of the late stage in equilibrium with quartz were $0.3 \%$ ond $-85.7 \%$, respectively, which were significantly lower than those of primary magmatic water. As shown in Figure 11, the decreasing trend of ore fluid $\delta^{18} \mathrm{O}_{\mathrm{H}_{2} \mathrm{O}}$ with time was paralleled with the slating trend of fluid inclusion microthermometric data, suggesting mixing between magmatic water and meteoric water [74].

In summary, the ore-forming fluids were mainly of magmatic origin, and the mixing of the ore fluids with meteoric water occurred during the late stage.

Sulfur isotopes are commonly used to trace the sources of ore-forming fluids [77-80], and studies on sulfides associated with Au mineralization can assist with understanding the sulfur source, and by inference, the source of $\mathrm{Au}$ in a hydrothermal system [81-83]. The $\delta^{34} \mathrm{~S}$ values of early stage pyrite (Py1-3) ranged from 2.9-4.3\%o (Table 3, Figure 13), with average values of 3.75\%. Py3-a and Py3-b had similar $\delta^{34} \mathrm{~S}$ values (3.9-4.3\%o and 3.5-3.8\%o, respectively) and showed no difference compared with Py1 and Py2 (3.4-4.3\%o and 2.9-3.8\%o, respectively) (Table 3, Figure 13). These characteristics indicated that the early-stage sulfur most likely came from a deep magma source $[84,85]$. 
The sulfur isotope compositions of pyrite, chalcopyrite, and galena from the middle stage yielded a wider range of $\delta^{34} \mathrm{~S}$ values from $-11.9-4.6 \%$ o (Table 3, Figure 13). The $\delta^{34} \mathrm{~S}$ values of pyrite and chalcopyrite had narrow ranges of $1.2-3.5 \%$ ond $0.9-4.6 \%$, respectively, and showed no difference between Py4 and Py5 (Table 3, Figure 13). This characteristic indicated that pyrite and chalcopyrite in the middle stage most likely came from a deep magma source [84,85].

However, the sulfur isotope compositions of galena yielded negative $\delta^{34} \mathrm{~S}$ values of $-11.9 \%$ o to $-7.0 \%$ o (Table 3, Figure 13), which differed distinctly from the values of other sulfides in the early and middle stages and showed enrichment in ${ }^{32} \mathrm{~S}$ and depletion in ${ }^{34} \mathrm{~S}$.

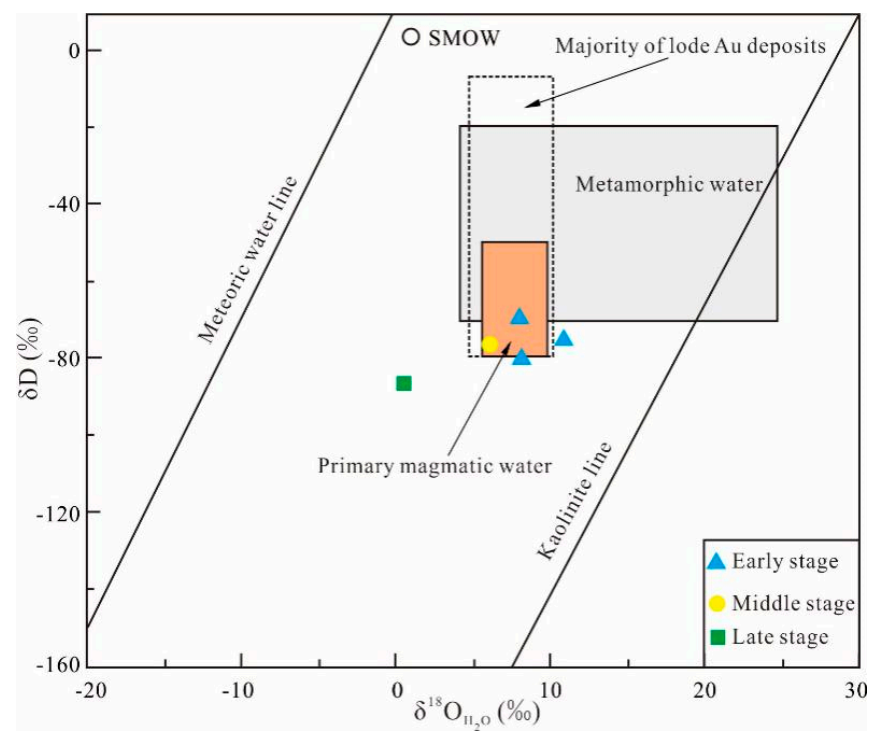

Figure 12. $\delta \mathrm{D}$ versus $\delta^{18} \mathrm{O}_{\mathrm{H}_{2} \mathrm{O}}$ plot of the isotopic compositions of the ore-forming fluids from the Liyuan gold deposit (following Reference [75]).

In conclusion, the $\delta^{34} \mathrm{~S}$ values of sulfides in the Liyuan gold deposit displayed a decreasing trend as follows: $\delta^{34} S_{\mathrm{Py}}(3.2 \%)>\delta^{34} \mathrm{~S}_{\mathrm{Ccp}}(2.2 \%)>\delta^{34} \mathrm{~S}_{\mathrm{Gn}}(-9.5 \%$ ). The sulfur isotope compositions of sulfides in a hydrothermal system are generally known to be influenced by not only the $\delta^{34} S$ values of source materials, but also temperature, oxygen fugacity, $\mathrm{pH}$, and ion activity of the ore-forming fluids [77]. Negative sulfur isotope compositions can be due to biological processes or sudden changes in oxygen fugacity [77]. No sedimentary sulfur has been found from any rocks in the central TM region. Then, sulfur minerals at Liyuan have no biologic texture, and the possibility of biologic processes can be excluded. As described earlier, the ore-forming fluids were mainly of magmatic origin and partly mixed with meteoric water during the late stage. Combining this information with the different $\delta^{34} S$ values among sulfides at the Liyuan deposit, we suggest that the negative $\delta^{34} S$ values of galena most likely reflected the oxidation of ore-forming fluids during the middle stage. Fluid oxidation can result from fluid-rock interaction [86], fluid boiling, or immiscibility [87]. As described above, fluid immiscibility was manifested in the study of FIs. The fluid-rock interactions between ore-forming fluids and wall rocks are extensive at Liyuan and are accompanied by widely developed sulfide alteration. In summary, we suggest that the sulfur of pyrite in the early and middle stages originated from a deep magma source and that subsequent fluid oxidation caused by a change in oxygen fugacity was responsible for the negative $\delta^{34} S$ values of galena. 


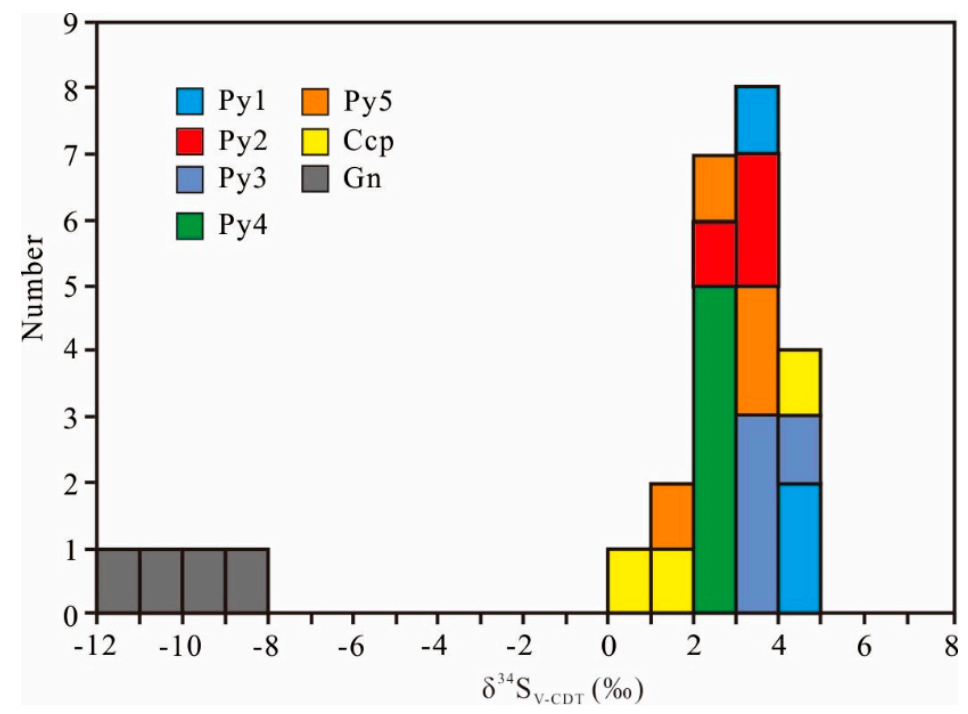

Figure 13. Histogram of in situ sulfur isotope data for the Liyuan gold deposit.

Approximately 220 sulfur isotope compositional data for sulfides were collected from the pluton and ore deposits in the central TM region in this study (Figure 14). The $\delta^{34} \mathrm{~S}$ values of the Yixingzhai, Xinzhuang, Shihu, and Xishimen gold deposits and the Diaoquan Ag-Cu deposit varied from $-2.2-5 \%$ o $[36,40,88,89]$, which was similar to the ranges for pyrite $(1.2-4.3 \%$ o $)$ and chalcopyrite $(0.9-4.6 \%$ o) in the Liyuan gold deposit. Moreover, the sulfur isotope composition of galena in the Liyuan deposit appeared to be similar to that of the Zhijiadi Ag-Pb-Zn deposit (Figure 14) [34]. Both deposits have similar geological settings and metallogenic characteristics. Compared with the $\delta^{34} S$ values of regional Early Cretaceous plutons (Sunzhuang quartz monzodiorite, 0.2-2\%o, [90]; Mapeng quartz diorite porphyrite, $0.6-2.6 \%$, [91]) and magmatic source $\left(\delta^{34} S=0 \pm 3 \%\right.$ o [92], the sulfur isotope compositions of pyrite and chalcopyrite in the Liyuan deposit were consistent, despite differences resulting from middle-stage galena.

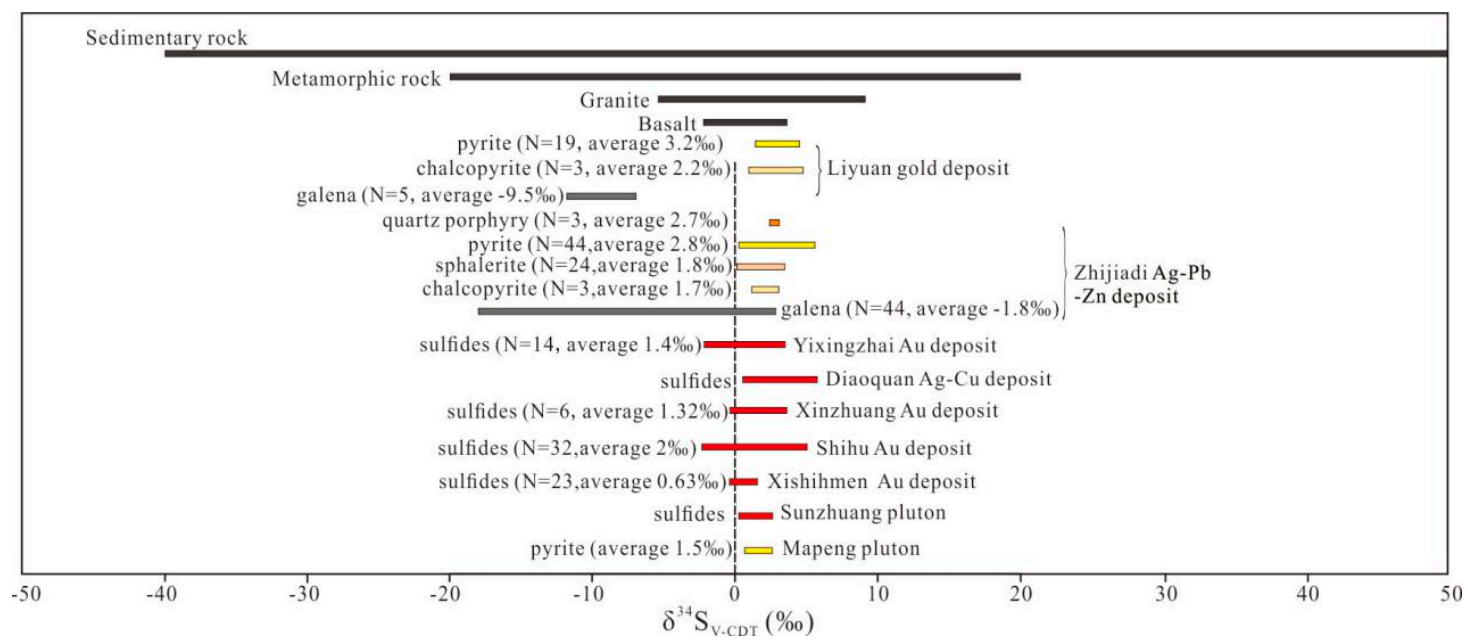

Figure 14. Sulfur isotope composition histograms of sulfide minerals from the plutons and ore deposits in the central Taihang Mountain region (following Reference [84,93]). References: Zhijiadi Ag-Pb-Zn deposit [34]; Yixingzhai gold deposit [36]; Diaoquan Ag-Cu deposit [88]; Xinzhuang gold deposit [89]; Shihu and Xishihmen gold deposit [32]; Sunzhuang [90]; and Mapeng batholith [91].

\subsubsection{Evolution of Ore-Forming Fluids}

Fluid inclusion petrography and microthermometry showed that the dominant type III FIs were found to coexist with type I and II FIs within quartz grains in the early stage. In this stage, 
laser Raman spectroscopy showed that the vapor phase of type I and II FIs was dominated by $\mathrm{CO}_{2}$ and $\mathrm{H}_{2} \mathrm{O}$ (Figure 10a,b). Type I and II FIs had similar $\mathrm{T}_{\mathrm{h}-\mathrm{CO}_{2}}$ temperatures, which ranged from 24.4-30.9 ${ }^{\circ} \mathrm{C}$ and $27.7-29.1{ }^{\circ} \mathrm{C}$, respectively. The peak $\mathrm{T}_{\mathrm{h}}$ values of type I and type III FIs were concentrated from $280-320^{\circ} \mathrm{C}$ (Figure 9a), with salinities ranging from 3.3-9.4 wt.\% and 2.9-13.7 wt.\% $\mathrm{NaCl}$ equivalent (Table 1), respectively. Moreover, the salinities of type III FIs (average of 8.03) were higher than those of type I FIs (average of 5.83), which indicated that ore-forming fluids gave rise to phase separation in the early stage [71,72]. Therefore, the initial ore-forming fluids belonged to the $\mathrm{H}_{2} \mathrm{O}-\mathrm{CO}_{2}-\mathrm{NaCl}$ homogeneous system, characterized by medium-low temperature, the presence of $\mathrm{CO}_{2}$, and medium-low salinity.

The middle stage also contained all three types of FIs. Laser Raman spectroscopy showed that the vapor bubbles of type I and II inclusions were dominated by $\mathrm{CO}_{2}$ and $\mathrm{H}_{2} \mathrm{O}$ (Figure 10c-e). Given that the $\mathrm{T}_{\mathrm{m}-\mathrm{CO}_{2}}$ temperatures of FIs in this stage were slightly lower than the triple point of pure $\mathrm{CO}_{2}$, trace amounts of $\mathrm{CH}_{4}$ or other gases may have been present [53]. Minor $\mathrm{CH}_{4}$ was identified in previous studies [21,23] and gas analyses of groups of crushed FIs (our unpublished data), although no $\mathrm{CH}_{4}$ or other gases were detected in this study. The salinities of type I FIs were estimated to be $2.4-10.2 \mathrm{wt.} \%$ $\mathrm{NaCl}$ equivalent (average of 6.26), which are slightly lower than those of type III FIs (2.2 to $12.3 \mathrm{wt} . \%$ $\mathrm{NaCl}$ equivalent, average of 7.56) (Table 1). This characteristic also indicated that phase separation of ore-forming fluids occurred in this stage [71,72]. The peak $\mathrm{T}_{\mathrm{h}}$ temperatures of type I and III FIs were concentrated from $220-260^{\circ} \mathrm{C}$ (Figure 9c). Combining this information with the characteristics of FIs, fluid immiscibility occurred in the early and middle stages (Figure 11). Thus, the ore-forming fluids belonged to the $\mathrm{H}_{2} \mathrm{O}-\mathrm{CO}_{2}-\mathrm{NaCl} \pm \mathrm{CH}_{4}$ system, which was characterized by lower temperatures than those of the early-stage fluids.

Compared with quartz from the earlier stages, the late stage contains only type III FIs, with lower salinities (1.6-7.1 wt.\% NaCl equivalent, average of 3.52; Table 1) and $\mathrm{T}_{h}$ (peak $\mathrm{T}_{\mathrm{h}}$ of 160-180 ${ }^{\circ} \mathrm{C}$; Figure 9e) and no evidence for fluid immiscibility. These features, the decreasing trend in microthermometric data (Figure 11), combined with the hydrogen-oxygen isotope data (Figure 12), further suggests the involvement of meteoric water in the late stage.

\subsection{Gold Deposition Mechanism}

In hydrothermal solutions, gold mainly migrates in two forms: (1) Gold bisulfide complexes $\left[\mathrm{Au}(\mathrm{HS})_{2}^{-}\right]$and (2) gold chloride complexes $\left(\mathrm{AuCl}^{2-}\right)$ [94-97]. $\mathrm{Au}(\mathrm{HS})_{2}^{-}$was associated with near-neutral to weakly acidic ore-forming fluids, sulfides (especially pyrite), and temperatures $<400{ }^{\circ} \mathrm{C}$ [95], whereas $\mathrm{AuCl}^{2-}$ was dominant in near-neutral to weakly alkaline, $\mathrm{H}_{2} \mathrm{~S}$-poor, high-salinity, ore-forming fluids at temperatures $>400{ }^{\circ} \mathrm{C}$ [96]. The fluid inclusion studies in this paper indicated that the ore fluids were medium-low salinities (2.4-13.7 wt.\% NaCl equivalent) and $213-364^{\circ} \mathrm{C}$. In addition, the well-developed feldspar-sericite mineral assemblages in quartz veins and alteration zones indicated that the $\mathrm{pH}$ values of ore-forming fluids at the Liyuan gold deposit were 5.2-6.8 [97], and $\mathrm{CO}_{2}$ could buffer the $\mathrm{pH}$ of the solution during gold transport [62]. Therefore, we inferred that $\mathrm{Au}(\mathrm{HS})_{2}^{-}$was the most likely species to transport gold, which is also supported by the close relationship between gold and sulfides (Figure 5c-f).

As noted above, the temperature of the fluids decreased from the early stage to the middle and late stages. Fluid immiscibility of the ore-forming fluids occurred from the early to middle stages, which caused phase separation of the fluids. These factors resulted in the escape of a large amount of gas (e.g., $\mathrm{CO}_{2}$ ) and consumption of $\mathrm{H}^{+}$as follows:

$$
\mathrm{H}^{+}+\mathrm{HCO}_{3}^{-}=\mathrm{CO}_{2}+\mathrm{H}_{2} \mathrm{O}
$$

As the activity of $\mathrm{H}^{+}$plays an important role in maintaining the stability of $\mathrm{HS}^{-}$and gold bisulfide $\left[\mathrm{Au}(\mathrm{HS})_{2}^{-}\right]$in the fluids, this process may have led to the decomposition of gold bisulfide [98]. Commonly, $\mathrm{H}_{2} \mathrm{~S}$ is an important medium for the transport and precipitation of gold. Along with fluid 
immiscibility, $\mathrm{H}_{2} \mathrm{~S}$ was fractionated from the liquid into the vapor phase, which also makes $\mathrm{Au}(\mathrm{HS})_{2}^{-}$ unstable $[99,100]$. Thus, gold precipitated from the ore-forming fluids.

Hydrothermal alteration, especially pyrite-sericite-quartz alteration (Figure 4f), is widespread in the Liyuan gold deposit. Geologic observation shows that hydrothermal breccias developed along the $F_{3}$ fault and No. 1 orebody (Figure $4 \mathrm{f}, \mathrm{j}$ ). This alteration may also imply that intense fluid-rock interaction occurred between iron-bearing wall rocks and ore-forming fluid when fluids migrated along the $\mathrm{F}_{3}$ fault. This process markedly changed the physical and chemical conditions and resulted in $\mathrm{H}_{2} \mathrm{~S}$ loss from the ore-forming fluids [101]. Subsequently, the fluid-rock interaction between ore-forming fluids and iron-bearing wall rocks generated pyrite, and the $\mathrm{pH}$ of the fluid increased by the release of $\mathrm{CO}_{2}$, which also decreased the stability of gold bisulfide and finally led to gold precipitation $[97,101]$. Field observations and petrographic studies showed that gold is associated with widely developed sulfidation, especially pyritization (Figure $5 c-f$ ). These findings suggested that the water-rock interaction model also played a role in gold precipitation.

In summary, we suggest that water-rock interactions and fluid immiscibility were the two main mechanisms for gold deposition at the Liyuan gold deposit.

\subsection{Ore Genesis}

Despite previous studies related to the origin and evolution of ore-forming fluids and material, the timing of mineralization, the genesis of the Liyuan gold deposit [20-23], the origin of ore-forming fluids, and genesis of this deposit remains controversial [21-23]. New data obtained in this study supports the interpretation that the Liyuan gold deposit might be classified as a magmatic-hydrothermal deposit and the origin of ore-forming fluids were sourced from magmatic fluid. The detailed reasons are as follows:

(1) The tectonic setting of the Liyuan gold deposit was distinct from that of typical orogenic gold deposits. Therefore, it is not very convincing to explain gold mineralization in this deposit as an orogenic gold deposit.

(2) The orebodies in the Liyuan gold deposit occurred within the Archean Fuping Group gneiss and migmatitic K-feldspar granite and were mainly controlled by faults. Altered, vein, and breccia-type ores were the main ore types. Gold was mainly deposited in pyrite during the middle stage. Mills et al. [102] reported that the ore element assemblage of Early Cretaceous gold deposits in the NCC was Au-Ag-Te-Pb-Zn-Cu and that the content of arsenic in the ores was low. However, arsenic was enriched in most typical orogenic gold deposits [102]. Moreover, the weakly developed carbonation in the Liyuan gold deposit indicated that the content of hydrothermal carbonate minerals during the late stage was significantly lower than that of orogenic gold deposits $(5-15 \%)[103,104]$. In general, these features also implied that classifying the Liyuan gold deposit as an orogenic type gold deposit is not suitable.

(3) There were no large granite bodies exposed at current mining levels in the Liyuan gold deposit, except for several quartz porphyry dikes (Figure 3). Ma et al. [22] reported a sericite ${ }^{40} \mathrm{Ar} /{ }^{39} \mathrm{Ar}$ plateau age of $133.3 \pm 1.2 \mathrm{Ma}$ for the timing of gold mineralization. This age was consistent with the zircon $\mathrm{U}-\mathrm{Pb}$ age of $134.1 \pm 1.1 \mathrm{Ma}$ for the quartz porphyry dikes [22]. Considering the diabase, which yielded LA-ICP-MS zircon U-Pb age of $1788 \pm 13 \mathrm{Ma}$ [23], it should be precluded. The accordant ages suggest close spatial and genetic relationship between quartz porphyry and gold mineralization.

(4) The FI data obtained in this paper showed that the ore-forming fluids were characterized by medium-low temperature, medium-low salinity, and $\mathrm{CO}_{2}$-bearing, which might suggest that this deposit belongs to an orogenic gold deposit. However, the H-O isotope data indicated that the ore-forming fluids originated from a magmatic system, which was different from metamorphic origin of the typical orogenic gold deposit. In addition, the $\mathrm{S}$ isotope compositions of ore sulfides indicated that the sulfur of the ore-forming materials was of magmatic origin with variations caused by the change in oxygen fugacity. A previous study showed that the $\mathrm{Pb}$ of ore sulfides and quartz porphyry dikes originated from the lower crust and that the $C$ in calcite might have had a deep-seated magmatic 
source [22]. These characteristics were similar to those of regional deposits of Shihu, Xinzhuang, Yixingzhai, and Zhijiadi exposed in the central Taihang Mountains, which could be explained by a magmatic-hydrothermal system. Geophysical survey data revealed that a concealed intermediate-acid granitic pluton might underlie the Liyuan orebodies [42]. Combining the fact that no other Early Cretaceous granitic rocks were found in current mining levels, we therefore inferred that the fluids of gold deposit and quartz porphyry might both have been exsolved from a concealed granite pluton at a deeper location.

To sum up, based on the geological setting, ore geology, hydrothermal alteration, FIs, and $\mathrm{H}-\mathrm{O}-\mathrm{S}$ isotope studies in this paper, in combination with results from a previous study related to the $\mathrm{C}-\mathrm{O}-\mathrm{S}-\mathrm{Pb}$ isotopes, gold mineralization, and magmatism age, we propose that the Liyuan gold deposit is a typical magmatic-hydrothermal gold deposit. This model implies that gold mineralization at the Liyuan gold deposit resulted from water-rock interaction and fluid immiscibility along NE-striking faults. A schematic diagram illustrating the ore-forming process is shown in Figure 15. The magmatic-hydrothermal fluid exsolved from the concealed granite from deep magma and migrated upwards along the faults to higher levels (Figure 15). The faults might have been the major channel of ore-forming fluid transporting from a depth. As the temperature and pressure decreased, water-rock interactions and fluid immiscibility took place, leading to the deposition of gold.

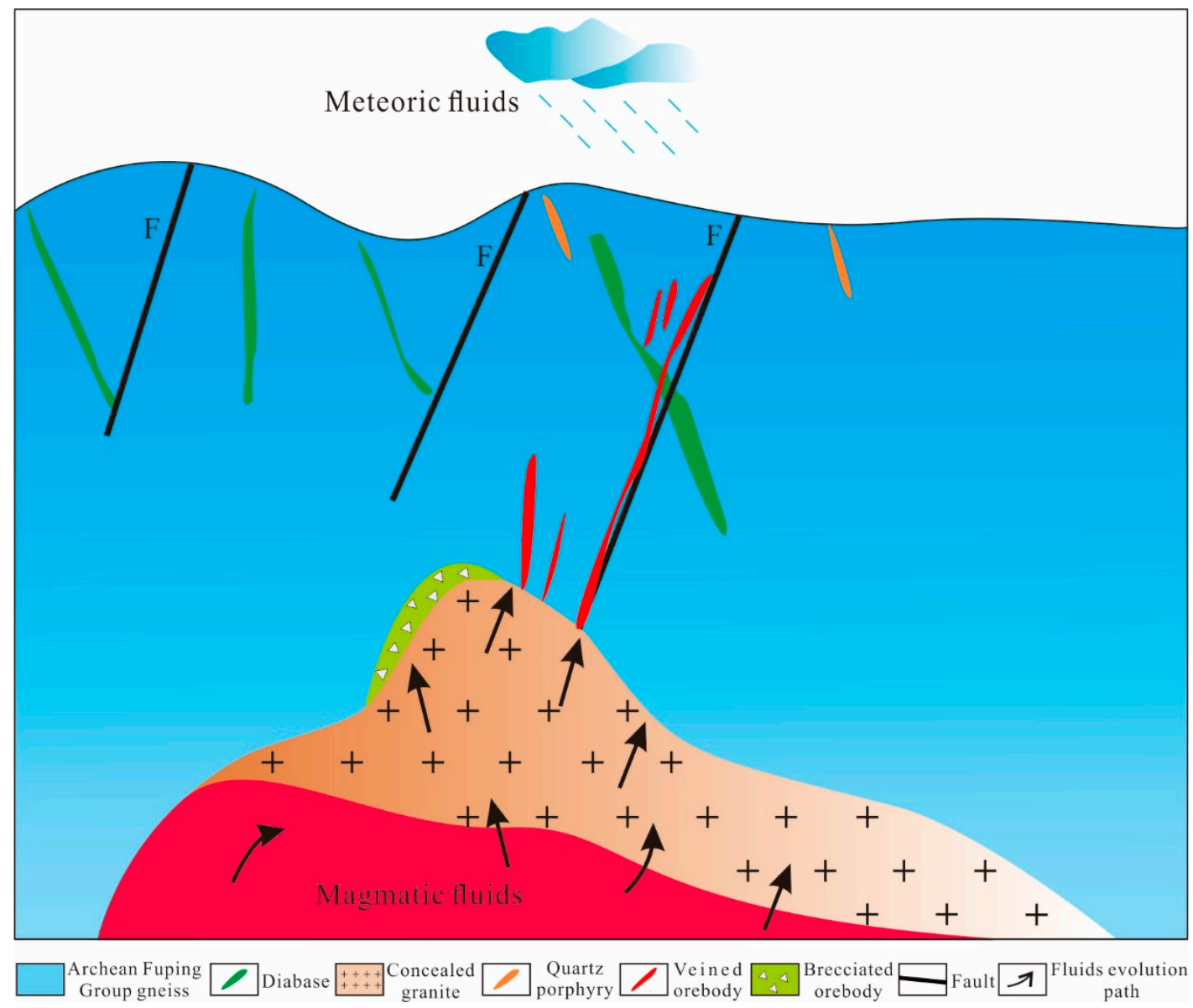

Figure 15. Schematic diagram illustrating the proposed genetic model for the Liyuan gold deposit.

\section{Conclusions}

(1) Three metallogenic stages were identified: A quartz-pyrite stage (early), a quartz-polymetallic sulfide stage (middle), and a quartz-carbonate stage (late).

(2) Three types of primary FIs were recognized: $\mathrm{CO}_{2}$-aqueous (type I), pure $\mathrm{CO}_{2}$ (type II), and aqueous FIs (type III). 
(3) The ore-forming fluids were characterized by medium-low temperature, medium-low salinity, and the $\mathrm{H}_{2} \mathrm{O}-\mathrm{CO}_{2}-\mathrm{NaCl} \pm \mathrm{CH}_{4}$ system, and fluid immiscibility occurred during the early and middle stages.

(4) The $\mathrm{H}-\mathrm{O}$ isotopes indicated that the ore-forming fluids were of magmatic origin in the early stage and may have been exsolved from a concealed granite pluton at deeper location.

(5) The $\mathrm{S}$ isotopes further confirmed that the sulfides were sourced from a deep magma with variations caused by the change in oxygen fugacity. $\mathrm{Au}(\mathrm{HS})_{2}^{-}$was most likely the species that was transporting gold in the Liyuan gold deposit. Water-rock interactions and fluid immiscibility were accepted as the two main mechanisms of gold deposition.

(6) Integration of the regional geology, ore geology, timing of mineralization, hydrothermal alteration, fluid inclusion, and H-O-S isotope study indicate that the Liyuan gold deposit is a magmatic hydrothermal deposit.

Author Contributions: X.Z., Z.P., and J.W. conceived and designed the ideas; X.Z., S.Z., H.J., and G.S. collected and analyzed the data; X.Z. wrote the manuscript; J.W., Z.P., J.X., and F.Y. revised and edited the manuscript.

Funding: This study was financially supported by China Geological Survey Project (No. DD20190570; No. DD20160071; No. DD20190815).

Acknowledgments: We are grateful to Editor and two anonymous reviewers from this journal for their constructive and helpful comments and suggestions. Also, we would like to thank Shaoyong Jiang, He Zhang, Guangxi Ou, and $\mathrm{Mu}$ Liu for their assistance with the lab word. We thank the staffs Jijie Song, Yongcai Fang, and Wenguo Dong from the Lingqiu Liyuan Mining Co. Ltd. (Datong, China) for their assistance in the field. Yuwang Wang, Qigui Mao from Beijing Institute of Geology for Mineral Resources and Hui Chen, Lei Yao, Lujun Lin from China Geological Survey are thanked for their valuable comments and constructive suggestions.

Conflicts of Interest: The authors declare no conflict of interest.

\section{References}

1. Groves, D.I.; Goldfarb, R.J.; Santosh, M. The conjunction of factors that lead to formation of giant gold provinces and deposits in non-arc settings. Geosci. Front. 2016, 7, 303-314. [CrossRef]

2. Groves, D.I.; Santosh, M. The giant Jiaodong gold province: The key to a unified model for orogenic gold deposits? Geosci. Front. 2016, 7, 409-417. [CrossRef]

3. Yang, F.; Santosh, M.; Kim, S.W. Mesozoic magmatism in the eastern North China Craton: Insights on tectonic cycles associated with progressive craton destruction. Gondwana Res. 2018, 60, 153-178. [CrossRef]

4. Yang, F.; Santosh, M.; Tang, L. Extensive crustal melting during craton destruction: Evidence from the Mesozoic magmatic suite of Junan, Eastern North China Craton. J. Asian Earth Sci. 2018, 157, 119-140. [CrossRef]

5. Li, S.R.; Santosh, M. Geodynamics of heterogeneous gold mineralization in the North China Craton and its relationship to lithospheric destruction. Gondwana Res. 2017, 50, 267-292. [CrossRef]

6. Goldfarb, R.J.; Taylor, R.D.; Collins, G.S.; Goryachev, N.A.; Orlandini, O.F. Phanerozoic continental growth and gold metallogeny of Asia. Gondwana Res. 2014, 25, 48-102. [CrossRef]

7. Sun, W.Y.; Li, S.R.; Santosh, M.; Wang, X.; Zhang, L.J. Isotope geochemistry and geochronology of the Qiubudong silver deposit, central North China Craton: Implications for ore genesis and lithospheric dynamics. Ore Geol. Rev. 2014, 57, 229-242. [CrossRef]

8. Yang, F.; Santosh, M.; Kim, S.W.; Zhou, H.; Jeong, Y.J. Late Mesozoic intraplate rhyolitic volcanism in the North China Craton: Far-field effect of the westward subduction of the Paleo-Pacific Plate. Geol. Soc. Am. Bull. 2019. [CrossRef]

9. Yang, F.; Xue, F.; Santosh, M.; Wang, G.; Kim, S.W.; Shen, Z.; Jia, W.; Zhang, X. Late Mesozoic magmatism in the East Qinling Orogen, China and its tectonic implications. Geosci. Front. 2019. [CrossRef]

10. Xu, Y.G.; Li, H.Y.; Pang, C.J.; He, B. On the timing and duration of the destruction of the North China Craton. Chin. Sci. Bull. 2009, 54, 1974-1989. (In Chinese with English Abstract) [CrossRef]

11. Zhang, J.J.; Zheng, Y.D. Multistage extension and age dating of the Xiaoqinling metamorphic core complex, central China. Acta Geol. Sin. 1999, 73, 139-147. 
12. Zhao, G.C.; Wilde, S.A.; Cawood, P.A.; Sun, M. Archean blocks and their boundaries in the North China Craton: Lithological, geochemical, structural and P-T path constraints and tectonic evolution. Precambrian Res. 2001, 107, 45-73. [CrossRef]

13. Davis, G.A.; Darby, B.J.; Yadong, Z.; Spell, T.L. Geometric and temporal evolution of an extensional detachment fault, Hohhot metamorphic core complex, Inner Mongolia, China. Geology 2002, 30, 1003-1006. [CrossRef]

14. Liu, J.L.; Davis, G.A.; Lin, Z.Y.; Wu, F.Y. The Liaonan metamorphic core complex, Southeastern Liaoning Province, North China: A likely contributor to Cretaceous rotation of Eastern Liaoning, Korea and contiguous areas. Tectonophysics 2005, 407, 65-80. [CrossRef]

15. Wu, F.Y.; Lin, J.Q.; Wilde, S.A.; Zhang, X.; Yang, J.H. Nature and significance of the Early Cretaceous giant igneous event in eastern China. Earth Planet. Sci. Lett. 2005, 233, 103-119. [CrossRef]

16. Chen, B.; Tian, W.; Jahn, B.M.; Chen, Z.C. Zircon SHRIMP U-Pb ages and in-situ Hf isotopic analysis for the mesozoic intrusions in South Taihang, North China Craton: Evidence for hybridization between mantle-derived magmas and crustal components. Lithos 2008, 102, 118-137. [CrossRef]

17. Mao, J.W.; Xie, G.Q.; Pirajno, F.; Ye, H.S.; Wang, Y.B.; Li, Y.F.; Xiang, J.F.; Zhao, H.J. Late Jurassic-Early Cretaceous granitoid magmatism in Eastern Qinling, central-eastern China: SHRIMP zircon U-Pb ages and tectonic implications. Aust. J. Earth Sci. 2010, 57, 51-78. [CrossRef]

18. Pei, F.P.; Xu, W.L.; Yang, D.B.; Yu, Y.; Wang, W.; Zhao, Q.G. Geochronology and geochemistry of Mesozoic mafic-ultramafic complexes in the southern Liaoning and southern Jilin provinces, NE China: Constraints on the spatial extent of destruction of the North China Craton. J. Asian Earth Sci. 2011, 40, 636-650. [CrossRef]

19. Li, J.W.; Bi, S.J.; Selby, D.; Chen, L.; Vasconcelos, P.; Thiede, D.; Zhou, M.F.; Zhao, X.F.; Li, Z.K.; Qiu, H.N. Giant Mesozoic gold provinces related to the destruction of the North China Craton. Earth Planet. Sci. Lett. 2012, 349, 26-37. [CrossRef]

20. Xu, X.P. Characteristics and genesis of Liyuan gold deposit in the Lingqiu County, Shanxi province. Huabei Land Resour. 2009, 3, 3-5. (In Chinese)

21. Ju, P.J.; Lai, J.Q.; Yang, H.J.; Wang, Y.J.; Song, J.J.; Li, L.Y.; Xu, X.B.; Dong, W.G.; Yang, B. Characteristics of fluid inclusions and mineralization of Liyuan gold deposit in Lingqiu County, Shanxi Province, China. Chin. J. Nonferrous Met. 2015, 25, 2537-2550. (In Chinese with English Abstract)

22. Ma, Y.; Jiang, S.Y.; Li, H.L. Isotope geochemistry and genesis of the Liyuan gold deposit, Shanxi, North China. Ore Geol. Rev. 2017, 92, 129-143. [CrossRef]

23. Ma, Y.; Xiong, S.F.; Li, H.L.; Jiang, S.Y. Origin and evolution of ore-forming fluids in the Liyuan gold deposit, central North China Craton: Constraints from fluid inclusions and H-O-C isotopic compositions. Geofluids 2017. [CrossRef]

24. Zhai, M.G.; Bian, A.G. Amalgamation of the supercontinental of the North China Craton and its break up during late-middle Proterozoic. Sci. China 2001, 43, 219-232. [CrossRef]

25. Zhai, M.G.; Guo, J.H.; Liu, W.J. Neoarchean to Paleoproterozoic continental volution and tectonic history of the North China Craton. J. Asian Earth Sci. 2005, 24, 547-561. [CrossRef]

26. Zhai, M.G. Cratonization and the Ancient North China Continent: A summary and review. Sci. China-Earth Sci. 2011, 54, 1110-1120. [CrossRef]

27. Zhai, M.G.; Santosh, M. The early Precambrian odyssey of the North China Craton: A synoptic overview. Gondwana Res. 2011, 20, 6-25. [CrossRef]

28. Santosh, M.; Teng, X.M.; He, X.F.; Tang, L.; Yang, Q.Y. Discovery of Neoarchean suprasubduction zone ophiolite suite from Yishui Complex in the North China Craton. Gondwana Res. 2016, 38, 1-27. [CrossRef]

29. Zhao, G.C.; Sun, M.; Wilde, S.A.; Li, S.Z. Late Archean to Paleoproterozoic evolution of the North China Craton: Key issues revisited. Precambrian Res. 2005, 136, 177-202. [CrossRef]

30. Zhang, H.; Liu, J.; Santosh, M.; Tao, N.; Zhou, Q.; Hu, B. Ultra-depleted peridotite xenoliths in the Northern Taihang Mountains: Implications for the nature of the lithospheric mantle beneath the North China Craton. Gondwana Res. 2017, 48, 72-85. [CrossRef]

31. Guan, H.; Sun, M.; Wilde, S.A.; Zhou, X.H.; Zhai, M.G. SHRIMP U-Pb zircon geochronology of the Fuping Complex: Implications for formation and assembly of the North China Craton. Precambrian Res. 2002, 113, 1-18. [CrossRef] 
32. Li, S.R.; Santosh, M.; Zhang, H.F.; Shen, J.F.; Dong, G.C.; Wang, J.Z.; Zhang, J.Q. Inhomogeneous lithospheric thinning in the central North China Craton: Zircon U-Pb and S-He-Ar isotopic record from magmatism and metallogeny in the Taihang Mountains. Gondwana Res. 2013, 23, 141-160. [CrossRef]

33. Fan, H.R.; Zhai, M.; Yang, K.F.; Hu, F.F. Late Mesozoic Gold Mineralization in the North China Craton. In Main Tectonic Events and Metallogeny of the North China Craton; Springer: Berlin/Heidelberg, Germany, 2016; pp. 511-525.

34. Liu, T.; Xiong, S.F.; Jiang, S.Y.; Li, H.L.; Chen, Q.Z.; Jiang, H. Genesis of the Zhijiadi Ag-Pb-Zn Deposit, Central North China Craton: Constraints from Fluid Inclusions and Stable Isotope Data. Geofluids 2017. [CrossRef]

35. Zhang, J.Q.; Li, S.R.; Santosh, M.; Li, Q.; Niu, S.D.; Li, Z.D.; Zhang, X.G.; Jia, L.B. Timing and origin of Mesozoic magmatism and metallogeny in the Wutai-Hengshan region: Implications for destruction of the North China Craton. J. Asian Earth Sci. 2015, 113, 677-694. [CrossRef]

36. Cao, Y.; Li, S.R.; Yao, M.J.; Zhang, H.F.; Jiang, S.Q.; Niu, H.P. Isotope geochemistry of the Shihu gold deposit, Hebei Province, North China: Implication for the source of ore fluid and materials. Carpathian J. Earth Environ. Sci. 2011, 6, 235-249.

37. Cao, Y.; Li, S.R.; Zhang, H.F.; Liu, X.B.; Li, Z.Z.; Ao, C.; Yao, M.J. Significance of zircon trace element geochemistry, the Shihu gold deposit, western Hebei Province, North China. J. Rare Earths 2011, 29, 277-286. [CrossRef]

38. Cao, Y.; Carranza, M.E.J.; Li, S.R.; Yao, M.J.; Zhang, H.F. Source and evolution of fluids in the Shihu gold deposit, Taihang Mountains, China: Evidence from microthermometry, chemical composition and noble gas isotope of fluid inclusions. Geochem.-Explor. Environ. Anal. 2012, 12, 177-191. [CrossRef]

39. Cao, Y.; Li, S.R.; Xiong, X.X.; Li, Z.Z.; Liu, X.B.; Yao, M.J.; Zhang, H.F. Laser ablation ICPMS U-Pb zircon geochronology of granitoids and quartz veins in the Shihu Gold Mine, Taihang orogeny, North China: Timing of gold-mineralization and tectonic implications. Acta Geol. Sin. 2012, 86, 1211-1224.

40. Li, S.R.; Santosh, M.; Zhang, H.F.; Luo, J.Y.; Zhang, J.Q.; Li, C.L.; Song, J.Y.; Zhang, X.B. Metallogeny in response to lithospheric thinning and craton destruction: Geochemistry and U-Pb zircon chronology of the Yixingzhai gold deposit, central North China Craton. Ore Geol. Rev. 2014, 56, 457-471. [CrossRef]

41. Zhang, D.C.; Zhang, C. The Geological Map of the Liyuan Gold Deposit; Shanxi Provincial Geological Prospecting Bureau: Datong, China, 2009. (In Chinese)

42. Jiang, S.Y.; Wen, C.G.; Li, H.L.; Wang, Y.; Jiang, H.; Liu, Q.; Zhang, L.; Zhi, Y.D.; Ren, R.; Zhou, P.; et al. The Report of Prospecting Prediction of Ore District, North Shanxi Province; China University of Geosciences (Wuhan): Wuhan, China, 2016.

43. Liu, B.; Shen, K. Thermodynamics of Fluid Inclusions; Geological Publishing House: Beijing, China, 1999. (In Chinese)

44. Lu, H.Z.; Fan, H.R.; Ni, P.; Ou, G.X.; Shen, K.; Zhang, W.H. Fluid Inclusion; Science Press: Beijing, China, 2004; pp. 1-487. (In Chinese)

45. Bodnar, R.J. Revised equation and table for determining the freezing point depression of $\mathrm{H}_{2} \mathrm{O}-\mathrm{NaCl}$ solutions. Geochim. Cosmochim. Acta 1993, 57, 683-684. [CrossRef]

46. Collins, P.L.F. Gas hydrates in $\mathrm{CO}_{2}$-bearing fluid inclusions and use freezing data for estimation of salinity. Econ. Geol. 1979, 74, 1435-1444. [CrossRef]

47. Brown, P.E. Flincor: A microcomputer program for the reduction and investigation of fluid-inclusion data. Am. Miner. 1989, 74, 1390-1393.

48. Clayton, R.N.; Mayeda, T.K. The use of bromine pentafluoride in the extraction of oxygen from oxides and silicates for isotopic analysis. Geochim. Cosmochim. Acta 1963, 27, 43-52. [CrossRef]

49. Zhu, Z.Y.; Cook, N.; Yang, T.; Ciobanu, C.; Zhao, K.D.; Jiang, S.Y. Mapping of Sulfur Isotopes and Trace Elements in Sulfides by LA-(MC)-ICP-MS: Potential Analytical Problems, Improvements and Implications. Minerals 2016, 6, 110. [CrossRef]

50. Zhu, Z.Y.; Jiang, S.Y.; Ciobanu, C.L.; Yang, T.; Cook, N.J. Sulfur isotope fractionation in pyrite during laser ablation: Implications for laser ablation multiple collector inductively coupled plasma mass spectrometry mapping. Chem. Geol. 2017, 450, 223-234. [CrossRef]

51. Pichavant, M.; Ramboz, C.; Weisbrod, A. Fluid immiscibility in natural processes: Use and misuse of fluid inclusion data: I. phase equilibria analysis-A theoretical and geometrical approach. Chem. Geol. 1982, 37, 29-48. [CrossRef] 
52. Kruger, Y.; Diamond, L.W. P-V-T-X properties of two $\mathrm{H}_{2} \mathrm{O}-\mathrm{CO}_{2}-\mathrm{NaCl}$ mixtures up to $850^{\circ} \mathrm{C}$ and $500 \mathrm{MPa}$ A synthetic fluid inclusion study. XVI ECROFI. Proc. Abstr. 2001, 7, 241-244.

53. Thiéry, R.; Van Den Kerkhof, A.M.; Dubessy, J. VX properties of $\mathrm{CH}_{4}-\mathrm{CO}_{2}$ and $\mathrm{CO}_{2}-\mathrm{N}_{2}$ fluid inclusions: Modelling for $\mathrm{T}<31{ }^{\circ} \mathrm{C}$ and $\mathrm{P}<400$ bars. Eur. J. Mineral. 1994, 6, 753-771.

54. Clayton, R.N.; O'Neil, J.R.; Mayeda, T.K. Oxygen isotope exchange between quartz and water. J. Geophys. Res. 1972, 77, 3057-3067. [CrossRef]

55. Anderson, M.R.; Rankin, A.H.; Spiro, B. Fluid mixing in the generation of isothermal gold mineralization in the Transvaal Sequence, Transvaal, South Africa. Eur. J. Mineral. 1992, 4, 933-948. [CrossRef]

56. Wilkinson, J.J. Fluid inclusions in hydrothermal ore deposits. Lithos 2001, 55, 229-272. [CrossRef]

57. Bakker, R.J.; Jansen, J.B.H. A mechanism for preferential $\mathrm{H}_{2} \mathrm{O}$ leakage from fluid inclusions in quartz, based on TEM observations. Contrib. Mineral. Petrol. 1994, 116, 7-20. [CrossRef]

58. Roedder, E. Fluid Inclusions as Samples of Ore Fluids. In Geochemistry of Hydrothermal Ore Deposits, 2nd ed.; Wiley: New York, NY, USA, 1979; pp. 684-737.

59. Bodnar, R.J. Reequilibration of fluid inclusions. In Fluid Inclusions: Analysis and Interpretation; Samson, I., Anderson, A., Marshall, D., Eds.; Mineralogical Association of Canada Short Course Series: la Couronne, QC, Canada, 2003; Volume 32, pp. 213-230.

60. Xavier, R.P.; Foster, R.P. Fluid evolution and chemical controls in the Fazenda Maria Preta (FMP) gold deposit, Rio Itapicuru greenstone belt, Bahia, Brazil. Chem. Geol. 1999, 154, 133-154. [CrossRef]

61. Neumayr, P.; Hagemann, S.G. Hydrothermal Fluid Evolution within the Cadillac Tectonic Zone, Abitibi Greenstone Belt, Canada: Relationship to Auriferous Fluids in Adjacent Second and Third-Order Shear Zones. Econ. Geol. 2002, 97, 1203-1225. [CrossRef]

62. Yang, L.Q.; Deng, J.; Guo, L.N.; Wang, Z.L.; Li, X.Z.; Li, J.L. Origin and evolution of ore fluid, and gold-deposition processes at the giant Taishang gold deposit, Jiaodong Peninsula, eastern China. Ore Geol. Rev. 2016, 72, 585-602. [CrossRef]

63. Wang, Z.L.; Yang, L.Q.; Guo, L.N.; Marsh, E.; Wang, J.P.; Liu, Y.; Zhang, C.; Li, R.H.; Zhang, L.; Zheng, X.L.; et al. Fluid immiscibility and gold deposition in the Xincheng deposit, Jiaodong Peninsula, China: A fluid inclusion study. Ore Geol. Rev. 2015, 65, 701-717. [CrossRef]

64. Ma, W.D.; Fan, H.R.; Liu, X.; Yang, K.F.; Hu, F.F.; Zhao, K.; Cai, Y.C.; Hu, H.L. Hydrothermal fluid evolution of the Jintingling gold deposit in the Jiaodong peninsula, China: Constraints from U-Pb age, CL imaging, fluid inclusion and stable isotope. J. Asian Earth Sci. 2018, 160, 287-303. [CrossRef]

65. Yang, L.Q.; Guo, L.N.; Wang, Z.L.; Zhao, R.X.; Song, M.C.; Zheng, X.L. Timing and mechanism of gold mineralization at the Wang'ershan gold deposit, Jiaodong Peninsula, eastern China. Ore Geol. Rev. 2017, 88, 491-510. [CrossRef]

66. Jiang, N. Hydrothermal Fluid Evolution Associated with Gold Mineralization at the Wenyu Mine, Xiaoqinling District, China. Resour. Geol. 2010, 50, 103-112. [CrossRef]

67. Zhao, C.; Ni, P.; Wang, G.G.; Ding, J.Y.; Chen, H.; Zhao, K.D.; Cai, Y.T.; Xu, Y.F. Geology, fluid inclusion, and isotope constraints on ore genesis of the Neoproterozoic Jinshan orogenic gold deposit, South China. Geofluids 2013, 13, 506-527. [CrossRef]

68. Roedder, E. Fluid inclusions. Rev. Mineral. 1984, 12, 1-664.

69. Olsen, S.N. High-density $\mathrm{CO}_{2}$ inclusions in the Colorado Front Range. Contrib. Mineral. Petrol. 1988, 100, 226-235. [CrossRef]

70. Hollister, L.S. Enrichment of $\mathrm{CO}_{2}$ in fluid inclusions in quartz by removal of $\mathrm{H}_{2} \mathrm{O}$ during crystal-plastic deformation. J. Struct. Geol. 1990, 12, 895-901. [CrossRef]

71. Coulibaly, Y.; Boiron, M.C.; Cathelineau, M.; Kouamelan, A.N. Fluid immiscibility and gold deposition in the birimian quartz veins of the angovia deposit (yaouré, ivory coast). J. Afr. Earth Sci. 2008, 50, 234-254. [CrossRef]

72. Lawrence, D.M.; Treloar, P.J.; Rankin, A.H.; Boyce, A.; Harbidge, P. A fluid inclusion and stable isotope study at the Loulo mining district, Mali, West Africa: Implications for multifluid sources in the generation of orogenic gold deposits. Econ. Geol. 2013, 108, 229-257. [CrossRef]

73. Lotfia, F.; Belkabira, A.; Brunetb, S.; Brownc, A.C.; Marcouxd, E. Lithogeochemical, mineralogical analyses and oxygen-hydrogen isotopes of the Hercynian Koudiat Aïcha massive sulphide deposit, Morocco. J. Afr. Earth Sci. 2010, 56, 150-166. [CrossRef] 
74. Wagner, T.; Mlynarczyk, M.S.J.; Williams-Jones, A.E.; Boyce, A.J. Stable isotope constraints on ore formation at the San Rafael Tin-Copper Deposit, Southeast Peru. Econ. Geol. 2009, 104, 223-248. [CrossRef]

75. Taylor, H.P. The application of oxygen and hydrogen isotope studies to problems of hydrothermal alteration and ore deposition. Econ. Geol. 1974, 69, 843-883. [CrossRef]

76. Zheng, Y.F. Stable Isotope Geochemistry; Science Press: Beijing, China, 2000; pp. 42-43.

77. Ohmoto, H. Systematics of sulfur and carbon isotopes in hydrothermal ore deposits. Econ. Geol. 1972, 67, 551-578. [CrossRef]

78. Ohmoto, H.; Rye, R. Isotopes of sulfur and carbon. In Geochemistry of Hydrothermal Ore Deposits; Barnes, H.L., Ed.; Wiley: New York, NY, USA, 1979; pp. 509-567.

79. Rye, R.O.; Ohmoto, H. Sulfur and Carbon Isotopes and Ore Genesis: A Review. Econ. Geol. 1974, 69, 826-842. [CrossRef]

80. Seal, R.R. Sulfur Isotope Geochemistry of Sulfide Minerals. Rev. Mineral. Geochem. 2006, 61, $633-677$. [CrossRef]

81. Kesler, S.E.; Riciputi, L.C.; Ye, Z. Evidence for a magmatic origin for Carlin-type gold deposits: Isotopic composition of sulfur in the Betze-Post-Screamer Deposit, Nevada, USA. Miner. Depos. 2005, 40, 127-136. [CrossRef]

82. Chang, Z.; Large, R.R.; Maslennikov, V. Sulfur isotopes in sediment-hosted orogenic gold deposits: Evidence for an early timing and a seawater sulfur source. Geology 2008, 36, 971-974. [CrossRef]

83. Ma, J.; Lü, X.; Escolme, A.; Li, S.; Zhao, N.; Cao, X.; Zhang, L.J.; Lu, F. In-situ sulfur isotope analysis of pyrite from the Pangjiahe gold deposit: Implications for variable sulfur sources in the north and south gold belt of the South Qinling orogen. Ore Geol. Rev. 2018, 98, 38-61. [CrossRef]

84. Hou, L.; Peng, H.J.; Ding, J.; Zhang, J.R.; Zhu, S.B.; Wu, S.Y.; Wu, Y.; Ouyang, H.G. Textures and in situ chemical and isotopic analyses of pyrite, Huijiabao Trend, Youjiang Basin, China: Implications for paragenesis and source of sulfur. Econ. Geol. 2016, 111, 331-353. [CrossRef]

85. Ohmoto, H. Stable isotope geochemistry of ore deposits. Rev. Mineral. Geochem. 1986, 16, 491-559.

86. Cameron, E.M.; Hattori, K. Archean gold mineralization and oxidized hydrothermal fluids. Econ. Geol. 1987, 82, 1177-1191. [CrossRef]

87. Drummond, S.E.; Ohmoto, H. Chemical evolution and mineral deposition in boiling hydrothermal systems. Econ. Geol. 1985, 80, 126-147. [CrossRef]

88. Li, S.Y.; Li, Z.L.; Lin, J.Y. Sub-Volcanic Type Ag-Mn-Au Deposits in the Northeast of Shanxi Province; China University of Geology Publishing House: Wuhan, China, 2000; pp. 1-241. (In Chinese)

89. Zhao, X.X. Research on the Geological and Geochemical Characteristics and Genesis of Xinzhuang Gold Deposit in Shanxi Province. Ph.D. Thesis, Central South University, Changsha, China, 2013. (In Chinese with English Abstract).

90. Jing, S.H. Metallogenetic condition of the Yixingzhai gold deposit, Fanshi County. Shanxi Geol. 1992, 7, 51-64. (In Chinese with English abstract)

91. Wang, Q.C.; Ma, J.L.; Zhang, J.Z. The geochemical characteristics of the Mapeng gold mine at the boundary between Lingshou and Fuping in Hebei province and the origin of the deposits. Geochimica 1995, 24, 57-68. (In Chinese with English abstract)

92. Chaussidon, M.; Lorand, J.P. Sulphur isotope composition of orogenic spinel lherzolite massifs from Ariege (North-Eastern Pyrenees, France): An ion microprobe study. Geochim. Cosmochim. Acta 1990, 54, 2835-2846. [CrossRef]

93. Ohmoto, H.; Goldhaber, M.B. Sulfur and carbon isotopes. In Geochemistry of Hydrothermal Ore Deposits; Barnes, H.L., Ed.; Wiley: New York, NY, USA, 1997; pp. 517-611.

94. Seward, T.M. Thio complexes of gold and the transport of gold in hydrothermal ore solutions. Geochim. Cosmochim. Acta 1973, 37, 379-399. [CrossRef]

95. Gammons, C.H.; Williams-Jones, A.E.; Yu, Y. New data on the stability of gold (I) chloride complexes at $300{ }^{\circ}$ C. Mineral. Mag. 1994, 58, 309-310. [CrossRef]

96. Benning, L.G.; Seward, T.M. Hydrosulphide complexing of gold (I) in hydrothermal solutions from 150 to $500{ }^{\circ} \mathrm{C}$ and 500 to 1500 bars. Geochim. Cosmochim. Acta 1996, 60, 1849-1871. [CrossRef]

97. Mikucki, E.J. Hydrothermal transport and depositional processes in Archean lode gold systems: A review. Ore Geol. Rev. 1998, 13, 307-321. [CrossRef] 
98. Chen, Y.J.; Ni, P.; Fan, H.R.; Pirajno, F.; Lai, Y.; Su, W.C.; Zhang, H. Diagnostic fluid inclusions of different types hydrothermal gold deposits. Acta Petrol. Sin. 2007, 23, 2085-2108. (In Chinese with English abstract)

99. Naden, J.; Shepherd, T.J. Role of methane and carbon dioxide in gold deposition. Nature 1989, 342, $793-795$. [CrossRef]

100. Wen, B.J.; Fan, H.R.; Santosh, M.; Hu, F.F.; Pirajno, F.; Yang, K.F. Genesis of two different types of gold mineralization in the linglong gold field, China: Constrains from geology, fluid inclusions and stable isotope. Ore Geol. Rev. 2015, 65, 643-658. [CrossRef]

101. Groves, D.I.; Phillips, G.; Ho, S.E.; Houstoun, S.M. The nature, genesis and regional controls of gold mineralization in Archaean greenstone belts of the Western Australian Shield; a brief review. S. Afr. J. Geol. 1985, 88, 135-148.

102. Mills, S.E.; Tomkins, A.G.; Weinberg, R.F.; Fan, H.R. Anomalously silver-rich vein-hosted mineralisation in disseminated-style gold deposits, Jiaodong gold district, China. Ore Geol. Rev. 2015, 68, 127-141. [CrossRef]

103. Zhu, R.X.; Fan, H.R.; Li, J.W.; Meng, Q.R.; Li, S.R.; Zeng, Q.D. Decratonic gold deposits. Sci. China-Earth Sci. 2015, 58, 1523-1537. [CrossRef]

104. Groves, D.I.; Goldfarb, R.J.; Gebremariam, M.; Hagemann, S.; Robert, F. Orogenic gold deposits: A proposed classification in the context of their crustal distribution and relationship to other gold deposit types. Ore Geol. Rev. 1998, 13, 7-27. [CrossRef]

(C) 2019 by the authors. Licensee MDPI, Basel, Switzerland. This article is an open access article distributed under the terms and conditions of the Creative Commons Attribution (CC BY) license (http://creativecommons.org/licenses/by/4.0/). 